\title{
A REFORMA PRISIONAL NA BAHIA OITOCENTISTA'
}

\author{
Cláudia Moraes Trindade \\ Doutoranda em História Social/UFBA
}

\begin{abstract}
Resumo
O objetivo deste artigo é contextualizar o início da reforma prisional baiana no século XIX. Discuto as heranças do encarceramento colonial, traço um panorama do quadro prisional da cidade de Salvador e relato a legislação prisional do Brasil recémindependente. Finalmente, também discuto os modelos penitenciários da Europa e Estados Unidos e os debates em torno da implantação da primeira penitenciária da província que recebeu o nome de Casa de Prisão com Trabalho.
\end{abstract}

\section{Pallavras-chaves}

Reforma prisional • penitenciária • Casa de Prisão com Trabalho • Bahia séc. XIX.

\section{Abstract}

The aim of this article is to contextualize the beginning of the prison reform in Bahia in the nineteenth century. I discuss the legacy of the colonial incarceration policy, I present a survey prison system in Salvador, as well as the legal rules established by the recently independent country. Finally, I also discuss the penitentiary models of Europe and United States and the debates regarding the building of the first penitentiary in the province, named Casa de Prisão com Trabalho (Workhouse Prison).

\section{Keywords}

Prison reform $\bullet$ penitentiary $\bullet$ Prison-Workhouse $\bullet$ Bahia 19th century.

\footnotetext{
${ }^{1}$ Este artigo é um desdobramento do primeiro capítulo da dissertação de mestrado intitulada $A$ Casa de Prisão com Trabalho da Bahia - 1833-1865, concluída em 2007, sob a orientação do prof. dr. João José Reis, a quem sou especialmente grata por seus comentários e indicação de fontes documentais e bibliográficas. A pesquisa contou com o apoio do Conselho Nacional de Desenvolvimento Científico e Tecnológico - CNPq. Os professores Cândido da Costa e Silva, Carlos Eugênio Líbano Soares, Pedro Moraes Trindade e Venétia Durando Braga Rios indicaram fontes documentais e bibliográficas, além de comentarem o texto. Agradeço os comentários feitos a uma versão anterior pelos membros da linha de pesquisa Escravidão e Invenção da Liberdade, do Programa de Pós-Graduação em História da UFBA. Sou igualmente grata aos pareceristas da Revista de História e ao seu editor, o prof. dr. Carlos Alberto de M. R. Zeron, cujas sugestões permitiram melhorar sensivelmente este artigo.
} 
Nas primeiras décadas do século XIX, ainda predominava na Bahia o sistema prisional instaurado pelos portugueses desde o início da colonização. Esse quadro começou a mudar a partir das décadas de 1820 e 1830, quando a discussão da reforma prisional tomou força em todo o Brasil. Além da influência de modelos europeus e norte-americanos, a Constituição do Império, em 1824, e a promulgação do Código Criminal, em 1830, foram importantes fatores que ajudaram a incluir o Brasil no contexto internacional da reforma prisional. ${ }^{2}$ Somando-se a esse quadro, o sentimento antilusitano que tomou conta das elites baianas, no período pós-independência, estimulou ainda mais as mudanças no aparato prisional da província. É o que podemos perceber no que foi escrito, em 1832, por uma comissão da Câmara Municipal de Salvador, responsável pelo melhoramento das prisões da cidade:

a ideia de atrazo da nossa civilização, e ainda miserável aluzão aos principios brutaes de um governo estupido, e desumano, qual o que pezou sobre o Brazil ate a epocha de sua Emancipação Politica, restringi-se a lembrar á Camara Municipal que a continuação da existencia da Cadeia Publica desta cidade nada menos importa que a continuação da corrupção fisica e moral não so dos prezos nella, como mesmo do resto dos habitantes. ${ }^{3}$

No antigo regime prisional a cadeia não tinha o objetivo de reabilitar; tampouco havia preocupação com a higiene e separação de presos pela qualidade do delito. O flagelo do corpo do criminoso era o conceito de punição. As questões criminais eram regidas pelo Livro V das Ordenações Filipinas, base legal de todo o Império luso, que vigorou no Brasil até a promulgação do Código Criminal em 1830. ${ }^{4}$ De acordo com as Ordenações Filipinas, a prisão servia para o infrator aguardar outros tipos de pena, como o açoite, degredo, morte etc.; ou quando se estipulava uma multa para um determinado delito, mantendo

\footnotetext{
${ }^{2}$ BRASIL. Constituição Política do Império do Brasil de 1824, título $8^{\circ}$, artigo 179, parágrafos, 18, 19 e 21; FILGUEIRAS JUNIOR Araujo. Código Criminal do Império do Brazil Annotado. Rio de Janeiro: Eduardo \& Henrique Laemmert, 1876.

${ }^{3}$ Relatório para o presidente e membros da Câmara Municipal de Salvador, 29.01.1832, Arquivo Municipal de Salvador (doravante AMS), Pareceres de Comissões.

${ }^{4}$ LARA, Silvia Hunold (org). Ordenações Filipinas: livro V. São Paulo: Companhia das Letras, 1999. Ver também HOLLOWAY, Thomas H. Polícia no Rio de Janeiro: repressão e resistência numa cidade do século XIX. Rio de Janeiro: Fundação Getúlio Vargas, 1997, p. 44.
} 
o indivíduo preso para garantir o pagamento. ${ }^{5}$ As cadeias localizavam-se nos centros urbanos, integrando-se ao cotidiano da cidade, facilitando a interação do preso com o mundo exterior. Essa era uma situação comum em todo o Império do Brasil. No Rio de Janeiro, a cadeia pública "tinha suas grades voltadas para a rua, o que mostrava aos passantes a terrível situação em que se encontravam os prisioneiros”. ${ }^{6}$ Essa interação proporcionava as mais diferentes relações entre os presos e os passantes, como na Corte, onde as negras quitandeiras costumavam vender os seus quitutes para os prisioneiros. ${ }^{7}$ Em São Paulo, a construção de uma calçada de pedra em volta da cadeia pública calhou aos "prisioneiros que viviam, como de praxe, dependurados às grades das suas enxovias a conversar com parentes e amigos [...]" ${ }^{8} \mathrm{Na}$ Bahia, esse contato foi registrado na cadeia da Relação, pois, ali, o boticário João Ladislau de Figueiredo Mello “conversava da rua com o amigo encarcerado [Cipriano Barata], separados pelas grades e sob a vista do carcereiro que olhava da janela”.

As esmolas dos passantes, que se sensibilizavam com o sórdido espetáculo, ajudavam os presos a sobreviver, enquanto aqueles que podiam contar com a ajuda de amigos e parentes tinham sua alimentação e a vestimenta garantidas. O poder público era conivente com a ajuda da população, pois apenas fornecia alimentação e roupas para aqueles que não contavam com a família ou amigos e que, por algum motivo, estavam impossibilitados de trabalhar. Eram os chamados “presos pobres”. Para alimentá-los, o governo mantinha um contrato com a Santa Casa da Misericórdia que fornecia a alimentação nas cadeias públicas da cidade. A má qualidade da comida da Santa Casa é tema constante, seja em representações de presos às autoridades, seja na correspondência do governo. ${ }^{10}$

\footnotetext{
${ }^{5}$ SALLA, Fernando. O encarceramento de São Paulo: das enxovias à Penitenciária do Estado. Tese de doutorado em Sociologia, Universidade de São Paulo, São Paulo, 1997, p. 20.

${ }^{6}$ ARAÚJO, Carlos Eduardo Moreira. O duplo cativeiro: escravidão urbana e o sistema prisional no Rio de Janeiro, 1790-1821. Dissertação de mestrado em História Social, Universidade Federal do Rio de Janeiro, Rio de Janeiro, 2004, p. 46.

${ }^{7}$ Em 1841, uma representação de presos da Casa de Correção da Corte, que se encontrava em construção, citava que as negras quitandeiras vendiam alimentos para eles através das grades. SOARES, Carlos Eugênio Líbano. A capoeira escrava e outras tradições rebeldes no Rio de Janeiro, 1808-1850. Campinas: Editora da Unicamp, 2003, p. 395.

${ }^{8}$ TAUNAY, Affonso de E. História social da cidade de São Paulo no século XIX, 1801-1822. São Paulo: Depto. de Cultura, vol. 3, p. 237, apud SALLA, op. cit., p. 24.

${ }^{9}$ MOREL, Marco. Cipriano Barata na Sentinela da Liberdade. Salvador: Academia de Letras da Bahia; Assembléia legislativa do Estado da Bahia, 2001, p. 78.

${ }^{10}$ Requerimento para o Governo da Província cobrando pagamento referente ao contrato de sustento dos presos, Arquivo da Santa Casa de Misericórdia da Bahia (doravante ASCMS), Li-
} 
Além do contato com as visitas e os transeuntes, o preso tinha a possibilidade de circular por outros ambientes quando obrigado a se ocupar em trabalhos públicos. ${ }^{11}$ Eram serviços geralmente desempenhados pelos condenados à pena de galés que trabalhavam acorrentados uns aos outros carregando água, desempenhando serviços de pedreiro, ou até combatendo formigas em lugares públicos e particulares, como aconteceu em São Paulo. ${ }^{12}$ Para o Rio de Janeiro, Carlos Eugênio Soares descreve as várias modalidades de trabalho forçado e formas de acorrentamento a que os presos, escravos ou não, eram submetidos no dique da ilha de Cobras. Uma dessas formas era o libambo - três ou mais escravos unidos por uma corrente que coletavam água para o abastecimento da ilha. ${ }^{13}$ Apesar do tratamento a que estavam sujeitos, os presos tinham algum contato com a cidade. Seja trabalhando, conversando com familiares ou comprando alimentos das quitandeiras, eles reproduziam antigos costumes que, mais tarde, os levariam a resistir à submissão das novas regras que seriam impostas pela instituição penitenciária.

Fernando Salla, em seu estudo sobre as prisões de São Paulo, observou que essa interação do preso com o mundo do lado de fora da prisão "revestia a Cadeia de um significado distinto daquele que viria a ter, algumas décadas depois, com a Casa de Correção”. ${ }^{14}$ O novo significado a que Salla se refere decorreu de uma nova interpretação do conceito de prisão e de punição que movimentou os debates em vários países durante o século XIX. O Brasil, na época, acompanhou uma tendência mundial que era a de reestruturar o aparelho

vro de Registros n ${ }^{\circ}$ 09/ A-93 fl. 30. Em 1833, o "contrato de sustento dos presos" entre a Santa Casa da Misericórdia e o Governo da Província custava aos cofres públicos “doze conto de reis annuaes”. Numa ocasião, os presos das cadeias do Barbalho e da Correção reclamaram ao chefe de polícia da péssima qualidade da comida da Santa Casa. O mordomo desta instituição alegou "que os presos pobres têm o costume de representar contra a Santa Casa toda vez que sabem que há novo Presidente ou novo Chefe de Policia, preparando até para isso, com reconhecida má fé rações [ilegível], e que lhes não são fornecidas, como por vezes se há verificado”. Mordomo para o chefe de polícia Polycarpio Lopes de Leão, 08.06.1858, ASCMS, Livro de Registros $n^{\circ} 9$ / A-93 fl. 210-211.

${ }^{11}$ Inicialmente, as Ordenações Filipinas determinavam que o condenado a galés fosse remetido às embarcações para remar. Posteriormente, essa pena foi comutada para trabalhos forçados em obras públicas. SALLA, op. cit., p. 39. Não confundir trabalhos forçados com pena de prisão com trabalho, cuja diferença será abordada adiante.

${ }^{12}$ Sobre os trabalhos forçados em São Paulo, ver SALLA, op. cit., p. 26.

${ }^{13}$ Para saber mais sobre o libambo, ver SOARES, op. cit., p. 258-259.

${ }^{14}$ SALLA, op. cit., p. 25. No Brasil oitocentista a instituição penitenciária também era chamada de Casa de Correção ou Casa de Prisão com Trabalho. 
prisional. Comparando as prisões do antigo regime com as penitenciárias, Michelle Perrot escreveu que, "no final do século XIX, coberta de lei, cercada de muros, ela [a prisão] se fecha cada vez mais. A ela não se escapa, assim como dela não se evade". ${ }^{15}$

As mudanças no aparelho prisional da Bahia aconteceram lentamente durante o século XIX. Atendendo à Lei Imperial de 1828, a Câmara Municipal de Salvador constituiu uma comissão de visitas às prisões e aos estabelecimentos pios que teve o objetivo de informar às autoridades sobre a situação em que se encontravam esses cárceres, além de sugerir os devidos melhoramentos. ${ }^{16}$ Essa era uma medida complementar ao artigo 179 da Constituição do Império que previa melhores cadeias. ${ }^{17}$ Em Salvador, a primeira comissão de visitas foi formada em 1829. As outras de que tive notícia foram as de 1832 e 1833. Entre os membros da primeira comissão estavam Antonio Pereira Rebouças, político, advogado, combatente da causa da independência e pai do abolicionista André Rebouças; outro membro era Manoel Maria do Amaral, advogado que, em 1864, governou a província na qualidade de vice-presidente. Da comissão de 1832 fazia parte o médico Manoel Maurício Rebouças, professor da Faculdade de Medicina da Bahia e irmão de Antonio Pereira Rebouças. Maurício Rebouças esteve também envolvido com os estudos sobre a teoria dos miasmas, muito em voga na época, quando o projeto liberal civilizatório que teve início nas primeiras décadas do século XIX buscou, entre outras medidas, higienizar a morte, pleiteando o enterro dos mortos nos cemitérios. ${ }^{18}$ Inspecionar e propor

\footnotetext{
${ }^{15}$ PERROT, Michele. Os excluídos da história: operários mulheres e prisioneiros. $3^{\mathrm{a}}$ edição, São Paulo: Paz e Terra, 2001, p. 241.

${ }^{16}$ BRASIL, Lei de $1^{\circ}$ de outubro de 1828, "Dá nova forma às Camaras Municipaes, marca suas atribuições, e o processo para a sua eleição, e dos Juizes de Paz”. Esta lei também estabeleceu que todos os assuntos relacionados à manutenção e construção das prisões, assim como aqueles relacionados aos presos, fossem de responsabilidade municipal e que todos os municípios do Império deveriam constituir as comissões de visitas. Sobre essa lei e sua relação com o projeto liberal civilizatório e higienizador em Salvador, ver REIS, João José. A morte é uma festa: ritos fúnebres e revolta popular no Brasil do século XIX. São Paulo: Companhia das Letras, 1991, p. 275-276. ${ }^{17}$ BRASIL. Constituição política do Império do Brazil, título $8^{\circ}$ parágrafo 21 . Estabeleceu que "as Cadêas serão seguras, limpas, bem arejadas, havendo diversas casas para separação dos Réos, conforme suas circumstancias, e natureza dos seus crimes”.

${ }^{18}$ Atas e mais objetos da comissão de visita das prisões civis e militares, 1829, AMS, Câmara; AMS, Pareceres de Comissões. Os pareceres da comissão de 1829 encontram-se completos; o mesmo não ocorre com os de 1832, dos quais localizei grande parte. Quanto aos da comissão de 1833, tive acesso apenas a algumas páginas do relatório. A primeira comissão constituída em 1829 era composta pelos seguintes membros: Gervásio de Souza Vieira, João Duarte Silva Uziel, Antonio Pereira Rebouças, Francisco Manoel Gonçalves da Cunha, Francisco de Paula de Araujo
} 
mudanças nas cadeias da cidade também fazia parte desse projeto da nova municipalidade após a lei de 28 de outubro de 1828 . As cadeias eram consideradas lugares insalubres e propícios à proliferação de doenças. Médicos, advogados, além dos engenheiros, estiveram presentes nas questões públicas durante o século XIX e, com a reforma prisional, não foi diferente.

Os pareceres dessas comissões de visita informam o estado das prisões religiosas, militares e civis de Salvador, na época em que as discussões sobre a reforma prisional começaram a tomar força na Bahia. Outra importante fonte de informação é a tese de doutoramento do médico João José Barboza d’Oliveira, pai do ilustre Rui Barbosa, sobre a higiene das cadeias, apresentada à Faculdade de Medicina de Salvador em 1843. ${ }^{19} \mathrm{O}$ dr. Barboza visitou as prisões militares e civis de Salvador, alguns anos depois das comissões da Câmara, e registrou em sua tese as impressões de suas visitas.

\section{Prisão eclesiástica e cárceres das ordens religiosas}

Até o ano de 1832, existia em Salvador uma prisão do clero, conhecida como Aljube, que foi construída, no século XVIII, por ordem do arcebispo José Botelho de Mattos. ${ }^{20}$ Localizado na Freguesia da Sé, na ladeira que levava o seu nome, seguindo em direção à ladeira da Praça, o Aljube servia exclusivamente

\footnotetext{
e Almeida e Manoel Maria do Amaral. A comissão de 1832 tinha como membros João Joaquim da Silva, Joaquim José da Rocha Bastos, Luis Tavares de Macedo e Francisco da Silva Azevedo da Roxa Vieira. A comissão de 1833 era constituída por Manoel Maurício Rebouças, Lucio Pereira de Azevedo, Athanazio da Silva Couto, João Antonio Monteiro e João Alexandre de Andrade Silva e Freitas. A composição desta última comissão consta na obra de OLIVEIRA, João José Barboza de. As prisões do paiz, o systema penitencial, ou hygiene penal. These apresentada, e sustentada perante a Faculdade de Medicina da Bahia, em 11 de dezembro de 1843. Bahia: Typ. de L. A. Portella e Companhia, 1843. Sobre a implantação dos cemitérios em Salvador, ver REIS, 1991, op. cit. Sobre Manoel Maurício Rebouças, ver, na mesma obra p. 255-256.

${ }^{19}$ OLIVEIRA, op. cit.

${ }^{20}$ Aljube, do árabe $a l-j u b$, significa cisterna, poço. Prisão de padres, cárcere de foro eclesiástico, caverna, gruta. FERREIRA, Aurélio Buarque de Holanda. Novo dicionário. Rio de Janeiro: Nova Fronteira, 1975, p. 71. É interessante a atribuição do nome Aljube para uma cadeia religiosa, se atentarmos para a interpretação de Thereza Baumann: “[...] o poço tem um peso simbólico expressivo, representa uma via de comunicação entre a terra e o céu e, inclusive, com a vida do além-túmulo [...]. Entre os hebreus é o signo da abundância, a fonte da vida [...]. Mas, ao mesmo tempo, é a imagem do abismo, das profundezas [...]”. BAUMANN, Thereza de B. Da iconografia, da loucura, da história. Revista de História Regional. Ponta Grossa: UFPG, vol. 2, nº 1, 1997, p. 16. A prisão do Aljube também existia em outras províncias como o Rio de Janeiro e Sergipe com data de fundação anterior à de Salvador. Em São Paulo, em 1818, foi reservado um cômodo da cadeia da Relação, que recebeu o nome de Aljube, para servir de prisão aos religiosos. SALLA, op. cit., p. 25.
} 
para os diocesanos e os cristãos leigos que cometiam delitos relacionados com a Igreja como, por exemplo, concubinato de leigos e clérigos, causas matrimoniais e testamentárias, heresia etc. Ao vigário geral, um dos auxiliares diretos do arcebispo, cabia "administrar a justiça, julgando delitos e aplicando penas" de acordo com as disposições do Regimento do Auditório Eclesiástico, datado de $1704 .^{21}$ Em 1829, a comissão de visita da Câmara Municipal constatou que as celas do Aljube ficavam no andar de cima, enquanto que o térreo servia de residência, situação que, segundo os membros da comissão, poderia facilitar a fuga de algum preso, sem contar que a fumaça da cozinha da casa impregnava as celas. Uma nova inspeção em 1832 o considerou uma boa prisão, porém recomendou que as privadas fossem retiradas de dentro das celas. ${ }^{22}$

Após a Independência do Brasil, a estrutura do poder repressor da Igreja foi abalada, dando início a muitas mudanças. Uma delas foi anunciada pela Portaria de 21 de maio de 1833, expedida pelo arcebispo da Bahia, d. Romualdo Antônio de Seixas. O documento dizia que "todas as penas eclesiásticas de prisão, multa ou degredo estavam abolidas”, permanecendo sob a jurisdição da Igreja somente as questões espirituais. Tal medida tornou desnecessária a manutenção do Aljube que foi em seguida desativado. ${ }^{23}$ Naquele mesmo ano, o clero alugou o prédio para o governo da província que, após realizar algumas adaptações, o transformou numa cadeia pública que também recebeu o nome de Aljube. Retomarei a discussão do Aljube adiante, quando tratar das cadeias civis.

Existiam também os cárceres das ordens religiosas que serviam para punir os religiosos que infringiam as regras internas dos conventos. Neste caso, eram os seus dirigentes quem aplicavam as punições. As ordens religiosas masculinas foram visitadas pelas comissões da Câmara de 1829 e 1832 e obtiveram boa avaliação. Contudo, o governo da Igreja não permitiu que fossem visitadas as ordens femininas. Ao ter o acesso negado, a comissão se posicionou dizendo "não estar de sua parte remover obstáculos que lhe oppoz o Governo Ecclesiástico”. ${ }^{24}$ Por fim, concluíram o relatório com um balanço positivo das prisões da Igreja.

\footnotetext{
${ }^{21}$ SILVA, Cândido da Costa e Silva. Os segadores e a messe: o clero oitocentista na Bahia. Salvador: SCT, EDUFBA, 2000, p. 125, 180, passim.

${ }^{22}$ Atas e mais objetos da comissão de visitas, op. cit., fl. $16 \mathrm{r}^{\circ}$ e Pareceres de comissões, op. cit.

${ }^{23}$ SILVA, 2000, op. cit., p. 132.

${ }^{24}$ Atas e mais objetos da comissão de visita das prisões civis e militares, op. cit., fl. 16v.
} 


\section{Prisões militares}

Salvador contava com muitas prisões militares, até mesmo pelas inúmeras fortalezas existentes na cidade. Sendo assim, citarei aquelas que tiveram maior significado nos acontecimentos do século XIX. Eram nas fortalezas que se localizavam os terríveis calabouços, úmidos, sem iluminação e pouco arejados. ${ }^{25}$ No forte de São Pedro, a comissão de 1829 encontrou dois calabouços que foram considerados péssimos. Em 1843, o dr. Barboza disse ter encontrado na mesma fortaleza, três celas "horrendamente escuras" e "muito calorosas” e todas ocupadas. Uma delas, com 11 soldados "mal vestidos, de camisa e calças sujas, num banho de suor", era muito baixa, com aproximadamente 5,5 metros de largura e 11 de comprimento. Quase sem iluminação, tinha o chão sujo e o ar impregnado pela "sentina asquerosa e putrida" ${ }^{26}$

Sobre o forte do Mar, a comissão de 1829 constatou que as celas ficavam nas abóbadas da fortaleza. Com exceção de cinco celas, destinadas aos militares e consideradas muito quentes, todas as outras eram escuras, com pouco ar e extremamente úmidas. ${ }^{27}$ Em 1832, a outra comissão declarou que as celas da fortaleza eram "destruidoras das vidas dos encarcerados". ${ }^{28}$ Rodeada pelo mar, esta fortaleza foi palco de importantes acontecimentos durante a década de 1830. Em 1832, as autoridades da Corte mandaram de volta à Bahia Cipriano Barata, um preso político indesejado, principalmente pelos métodos que utilizava para resistir às arbitrariedades das autoridades da Corte. Cipriano causava incômodo porque redigia seus jornais de dentro da prisão, aproveitando para denunciar os abusos do poder. Conforme escreve Marco Morel, os tribunais do Rio de Janeiro se viram incompetentes para julgar Cipriano Barata, decidindo por sua transferência para a Bahia, onde foi condenado a dez anos de prisão com trabalho, pena que teria sido comutada para 16 anos de prisão simples.

Em agosto de 1832, Cipriano estava preso no forte do Mar, onde se juntou a outros presos políticos como o sargento-mor Sergio José Veloso, comandante do forte do Mar, o tenente da Marinha Caetano Alvares de Sousa, comandante de um dos navios-prisões, entre outros. Naqueles dias de agosto, Cipriano escolheu

\footnotetext{
${ }^{25}$ Para Salvador, a documentação sugere a existência de calabouços somente nas fortalezas e nos quartéis que, pelo visto, nem sempre ficavam no subterrâneo. Situação diferente do Rio de Janeiro e São Paulo, que faziam uso de calabouços para escravos até mesmo nas penitenciárias.

${ }^{26}$ OLIVEIRA, op. cit., p. 25.

${ }^{27}$ Atas e mais objetos da comissão de visita das prisões civis e militares, op. cit., fls. 15-16.

${ }^{28}$ Pareceres de comissões, op. cit.
} 
a fortaleza e os companheiros de prisão para testemunharem a cerimônia do seu segundo casamento com Ana Joaquina de Oliveira Barata, de 47 anos, com quem já tinha cinco filhos. ${ }^{29}$ Os acontecimentos não pararam por aí. Em 1833, presos políticos, com a ajuda da guarnição da fortaleza do Mar, desencadearam a segunda revolta federalista e Cipriano foi apontado como chefe do motim, embora não estivesse envolvido de fato no episódio. ${ }^{30}$ Entre as reivindicações dos federalistas estava a reforma do Código Criminal de 1830 e o fim dos navios-prisões, dos quais tratarei adiante. ${ }^{31} \mathrm{~A}$ fortaleza do Mar também era requisitada pelo chefe de polícia, quando a prioridade era a segurança. Em 1835, por exemplo, foram mandados para lá cerca de 120 africanos, entre escravos e libertos, implicados no levante dos malês. ${ }^{32}$ No ano de 1842 , enquanto a cadeia da Relação passava por reformas, cerca de cinqüenta presos foram transferidos para a fortaleza do Mar e, segundo o chefe de polícia, ali eles estariam “em perfeita segurança”. ${ }^{33}$

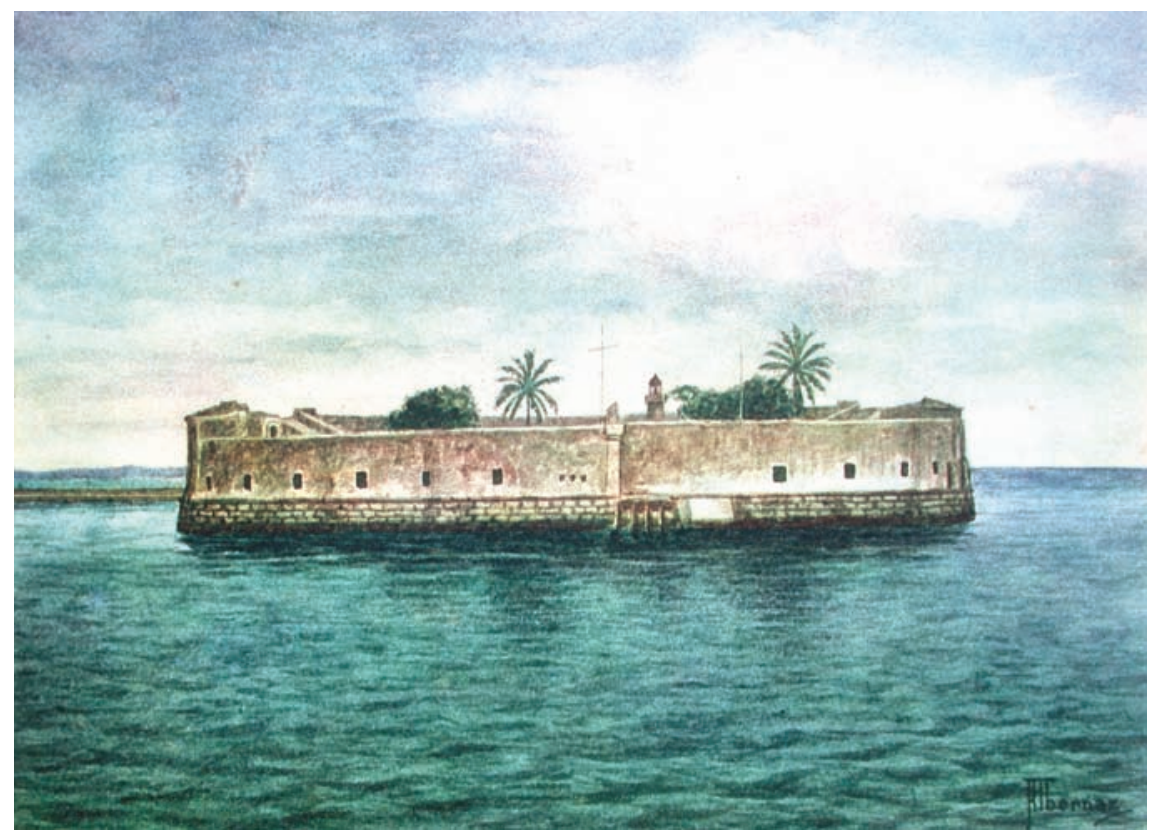

\footnotetext{
${ }^{29}$ Sobre este episódio e outros da vida de Cipriano Barata, ver MOREL, op. cit., p. 277-278.

${ }^{30}$ Ibid., p. 282-284.

${ }^{31}$ REIS, João José. Rebelião escrava no Brasil: a história do levante dos malês em 1835. Edição revista e ampliada. São Paulo: Companhia das Letras, 2003, p. 60.

${ }^{32}$ Sobre a revolta federalista e a prisão dos africanos ver ibid., p. 57-67 e p. 435.

${ }^{33}$ Chefe de polícia ao presidente da província, 02.09.1842, APEBa, Chefe de polícia, 1842, maço 2950.
} 
O Arsenal da Marinha administrava a prisão “dos galés”. ${ }^{34} \mathrm{O}$ motivo de tal denominação se devia ao fato desta prisão abrigar os sentenciados a penas de galés, inclusive presos civis. Em 1829, a comissão da Câmara constatou que a prisão “dos galés” era razoável, embora pequena. No Arsenal também existiam celas reservadas para os oficiais e marinheiros estrangeiros, como, por exemplo, um “quartinho por baixo de uma escada” onde os marinheiros ingleses eram detidos a mando do seu cônsul. Segundo o dr. Barbosa, tal cômodo, que comportava apenas uma pessoa, era privado de ar e com buracos pelo chão em meio à imundície. ${ }^{35}$

Por último, os navios-prisões que eram administrados pelo Arsenal da Marinha e serviam de prisão para presos políticos e militares. Embora o dr. Barboza informe que a comissão da Câmara de 1833 esteve nessas embarcações, não localizei o parecer destas visitas. ${ }^{36}$ No entanto, outros documentos nos permitem conhecer um pouco sobre elas. A mais conhecida, e talvez a mais temida, era a presiganga: o navio-prisão que Cipriano Barata chamou de "idiondo ergastulo”. ${ }^{37}$ Além deste, outros apelidos foram atribuídos à embarcação, como “Touro de Pirilo”, "Retrato do Inferno” e "Cárcere Horrível da Inquisição”. ${ }^{38}$ Segundo João Reis, "o navio-prisão derivava seu nome das infames press gangs, grupos a soldo do Estado que na Inglaterra e suas colônias recrutavam marinheiros à força entre a população pobre!” ${ }^{39}$ Consta que a presiganga da Bahia teria sido a antiga fragata Piranga, “de inestimáveis serviços prestados à causa da nossa independência, integrando a esquadra de Cochrane [...]”. ${ }^{40}$ Essa embarcação teria sido transformada em prisão em 1824. Além da Bahia,

\footnotetext{
${ }^{34}$ Segundo o dr. Barboza, a prisão do Arsenal da Marinha foi fundada em 1592. OLIVEIRA, op. cit., p. 26. Não encontrei exatamente o ano da sua extinção; no entanto, ela aparece nas estatísticas dos relatórios de presidente da província até o ano de 1879, época em que abrigava 27 forçados. BAHIA. Relatório do chefe de polícia José Antonio Rocha Viana, p. 8, Falla com que abriu no dia 1.o de maio de 1879 a 2. a sessão da 22. a legislatura da Assembléia Legislativa Provincial da Bahia o exm. sr. dr. Antonio de Araujo de Aragão Bulcão. Bahia: Typ. do Diario da Bahia, 1879.

${ }^{35}$ Atas e mais objetos da comissão de visita das prisões civis e militares, op. cit. fl. $26 \mathrm{r}^{\circ}$.

${ }^{36}$ OLIVEIRA, op. cit., p. 23 , nota 7.

${ }^{37}$ Jornal O Portacolo, 09.08.1832.

${ }^{38}$ SILVA, Alberto. A cidade de Salvador: aspectos seculares. Salvador: Imprensa Oficial da Bahia, 1971, p. 65.

${ }^{39}$ REIS, 2003, op. cit., p. 60.

${ }^{40}$ SILVA, 1971, op. cit., p. 65.
} 
existiam presigangas nas províncias de Pernambuco, Pará, Rio Grande do Sul, Rio de Janeiro e São Paulo. ${ }^{41}$

Preso na fortaleza do Mar, Cipriano Barata desafiou as autoridades baianas publicando, enquanto estava preso, em novembro de 1832, o jornal Sentinela da Liberdade na Guarita do Quartel General de Pirajá, mudada despoticamente para o Rio de Janeiro e de lá para o Forte do Mar da Bahia, donde generosamente brada Alerta! Como castigo, Cipriano foi transferido para a presiganga. ${ }^{42}$ Inconformado com a sua situação, ele redigiu um extenso requerimento ao ouvidor do Crime, Joaquim de Castro Mascarenhas, solicitando "para que sem demora, nem barulho de muita gente" ele fosse transferido para o forte do Barbalho ou do Mar. Segundo Barata, a "espelunca marítima de horrorosa carnificina" estava "podre", fazendo com que ele e mais 200 presos corressem perigo de se afogarem "em qualquer furacão, que acometta a presiganga; a qual apezar dos tapumes de carvão pizado com sebo, e chapas de chumbo, e outros remedios, augmentou de repente, e dobrou as agoas e os perigos, e não promete segurança alguma”, ${ }^{43}$ Cipriano adoeceu e foi transferido para o hospital Militar. Ao se recuperar, foi mandado, novamente, para a fortaleza do Mar. ${ }^{44}$

Segundo um jornal da época, a presiganga era uma "casa de tormento escura, abafada, quente e imunda; tão imunda e tão quente que os presos tinham que se conservar de todo nus padecendo de enfermidades da pele, como chagas, sarnas e erisipelas, originadas não só pelo ar abafado e miasmas pestilentos que exala o antro, mas ainda pela transpiração de corpos, pois às vezes se contam ali 400 infelizes". Esta seria a descrição do local onde ficava a maioria dos prisioneiros. Mas tinha ainda o porão da embarcação, reservado para os rebeldes. Era uma "caverna medonha e escura como a noite, permanecia constantemente com 30

\footnotetext{
${ }^{41}$ Dissertação abreviada sobre a horrível masmorra chamada - Preziganga - existente no Rio de Janeiro, datada de 26 e maio de 1829, Instituto Histórico e Geográfico Brasileiro, lata 48, pasta 12. A autoria desse documento é atribuída a Cipriano Barata. Agradeço a Carlos Eugênio Líbano por disponibilizar cópia do mesmo. Luis Henrique Dias Tavares divulgou este documento em Ecos do porão, Nossa História. Rio de Janeiro: ano 1, n 12 , outubro, 2004, p. 70-74. Sobre a presiganga do Rio de Janeiro, ver ainda SOARES, op. cit., especialmente capítulo 4. A presiganga de São Paulo ficava na cidade portuária de Santos e serviu de prisão, em 1833, para Francisco José de Souza Soares de Andréa que governou a Bahia em 1845. WILDBERGER, Arnoldo. Os presidentes da província da Bahia, efetivos e interinos. Cidade do Salvador: Tipografia Beneditina, 1949 , p. 273-288.

${ }^{42}$ MOREL, op. cit., p. 280-281.

${ }^{43}$ Jornal O Portacolo, 08.08.1832.

${ }^{44}$ MOREL, op. cit., p. 281.
} 
a 40 polegadas de água, habitada por uma infinidade de ratos e répteis imundos e venenosos". ${ }^{45}$

Outros navios-prisões, embora não levassem o nome de presiganga, também flutuavam nas águas da baía de Todos os Santos. Em 1838, Daniel Roiz de Santa Anna estava preso na fragata Bahiana acusado de ter participado da rebelião que ficou conhecida como Sabinada ${ }^{46}$ Em maio de 1838, João Carneiro da Silva Rego e o bacharel João Carneiro da Silva Rego filho estavam presos na corveta 7 de Abril. Eles solicitaram ao governo da província que os transferissem para a cadeia da Relação "ou qualquer outra prisão de terra, onde a lei encontra garantias, e onde os Supplicantes possão recorrer a suas familias [...] e aderir com facilidade meio honesto de subsistência, o que sem duvida não podem fazer onde se achão" ${ }^{47} \mathrm{O}$ documento não especifica o motivo que os levou para lá, mas, levando em consideração o período e o perfil da dupla, é possível que estivesse relacionado ao movimento da Sabinada. Na mesma corveta estava o sargento Manoel Sebastião de Santa Rita que agonizava devido ao castigo que sofrera de "cento e tantas pranxadas" por ter caluniado um português. ${ }^{48}$ Não encontrei a data exata da desativação dos navios-prisões, porém, em 1843, o dr. Barboza informou que eles já tinham sido extintos: “felizmente entre nós não ha actualmente esses vastos tumulos fluctuantes. [...]. Queira Deus que ja nunca mais o delirio das victorias civis, nem a sanha da vingança as ressuscite!” ${ }^{49}$

Em 1829, época das visitas da primeira comissão da Câmara, a Relação era a única cadeia civil de Salvador. Fundada em 1660, essa cadeia funcionava no subsolo da Câmara Municipal. ${ }^{50}$ Segundo a comissão, a enxovia masculina era um "pavoroso abismo" onde existiam quase duzentos homens famintos, "cobertos de nudez, e de miseria, mal alimentados pela Santa Casa da Misericordia.” Num espaço menor e com apenas dois corredores estreitos e em péssimas condições de higiene ficava a prisão das mulheres, onde estavam "simultaneamente confundidas as livres, as escravas, as criminosas e as apenas acusadas”. ${ }^{51}$

\footnotetext{
${ }^{45}$ Jornal O Portacolo, 18.08.1832, apud SILVA, 1971, op. cit., p. 65-66.

${ }^{46}$ Sobre a Sabinada, ver, SOUZA, Paulo Cezar. A Sabinada: revolta separatista da Bahia (1837). São Paulo: Brasiliense, 1987.

${ }^{47}$ APEBa, Policia (assuntos), 1832-1841, maço 3109.

${ }^{48}$ Pranchada é o mesmo que levar golpe de espada ou sabre.

${ }^{49}$ OLIVEIRA, op. cit., p. 23.

${ }^{50}$ Ibid., p. 19.

${ }^{51}$ Atas e mais objetos da comissão de visita das prisões civis e militares, op. cit., fls. $7 \mathrm{v}-8 \mathrm{v}$. As medidas originais da enxovia dos homens são 48 pés de comprimento por 26 pés de largura, e as
} 
Bem próxima das celas do sótão ficava a sala de audiência dos juízes de fora. Em 22 de julho de 1835, alguns meses depois da revolta dos malês, época em que a repressão policial aos africanos era ainda mais violenta, quatro membros da Câmara escreveram ao presidente da província reclamando do carcereiro que castigava os escravos "nas horas das Sessões da Câmara”. Segundo os solicitantes, esta atitude era um "escândalo” e uma "falta de respeito”. Eles pediam que tais castigos fossem transferidos para algum lugar público como, por exemplo, o Campo da Pólvora, onde já existia “um poste”, ou então que o carcereiro açoitasse os escravos em outros horários, evitando assim as "perturbações que causam nos trabalhos”. Os escravos continuaram sendo castigados na cadeia, porém, em horários que não "atrapalhassem” as reuniões municipais. ${ }^{52}$ A proximidade entre os dirigentes da cidade e os presos se repetia em outras prisões da Casa de Câmara e Cadeia do país, como, por exemplo, a de São Paulo, onde as enxovias ficavam embaixo da sala dos juízes: "Os 'homens bons' e notáveis que conduziam a vida da cidade tinham a seus pés os criminosos e ao menos algumas vezes por mês, durante as reuniões da Câmara, conviviam muito proximamente com eles, seus ruídos, seus odores". ${ }^{33}$

Com a reforma do Código do Processo Criminal, em 1841, as cadeias civis do Império ficaram obrigadas a seguir um regulamento que deveria ser elaborado pela polícia. ${ }^{54}$ A cadeia da Relação teve o seu implantado em 1843, e o mesmo estipulou que ela deveria ser destinada para infratores de condição livre e distribui os seus presos conforme consta no quadro 1.

distâncias dos corredores 6 pés de largura. Affonso Ruy, em obra que trata da história da Relação da Bahia, sequer mencionou a existência da cadeia. RUY, Affonso. A Relação da Bahia, contribuição para a História judiciária do Brasil. $2^{\mathrm{a}}$ edição. Salvador: Tribunal de Justiça do Estado da Bahia, 1996.

52 João Antunes de Azevedo Marques, Marechal Pereira Heitor de Macedo, Lucio Pereira d'Azevedo, Ignacio Accioli e Joaquim Galeão ao vice-presidente da província, 22.07.1835, APEBa, Correspondência recebida da Câmara de Salvador, 1834-1835, maço 1395.

${ }^{53}$ SALLA, op. cit., p. 25.

${ }^{54}$ A Lei n ${ }^{\circ} 261$, de 3 de dezembro de 1841; Regulamento para a cadeia da Relação da província da Bahia, 17.08.1843, APEBa, Mapa de presos, 1831-1849, maço 6269. 


\begin{tabular}{|l|l|}
\hline \multicolumn{2}{|c|}{ Quadro 1 - Plano de distribuição dos presos na cadeia da Relação em 1843} \\
\hline \multicolumn{1}{|c|}{ Prisão } & \multicolumn{1}{c|}{ Presos } \\
\hline Sala livre & Para os simplesmente detidos \\
\hline Sala do oratório & Sentenciados \\
\hline Sótão & Simplesmente acusados \\
\hline Sala fechada & Pronunciados em geral \\
\hline Enxovia dos homens & Sentenciados a galés, prisão perpétua e pena de 6 a 20 anos \\
\hline Entre-portas & Libertos africanos em custódia e os pronunciados por crimes menos graves \\
\hline Prisão das mulheres & $\begin{array}{l}\text { No } 1^{\circ} \text { andar as pronunciadas e sentenciadas até penas de } 6 \text { anos. No } 2^{\circ} \\
\text { andar, sentenciadas acima de } 6 \text { anos }\end{array}$ \\
\hline $\begin{array}{l}\text { Fonte: Regulamento para a cadeia da Relação da província da Bahia, 17.08.1843, APEBa, Mapa de presos, } \\
\text { 1831-1849, maço 6269. }\end{array}$ \\
\hline
\end{tabular}

Essas mudanças não aliviaram a situação dos presos que continuaram sofrendo privações de alimentos e vestimentas, além de serem maltratados pela superlotação das celas. ${ }^{55}$ Em 1844, por exemplo, a chamada "sala fechada", destinada aos presos pronunciados, estava com uma superlotação de 51 homens. O carcereiro escolheu 10 deles, que estavam pronunciados por crime de morte, e os transferiu para a cela da enxovia que, segundo o regulamento, deveria ser exclusiva para sentenciados a pena de galés e outras sentenças com duração entre seis e 20 anos. Nota-se que a separação de presos pela natureza dos crimes, prevista na Constituição, não foi respeitada. A justificativa do carcereiro foi que "reos dessa natureza sempre forão ali conservados [na cela da enxovia]" ${ }^{56}$ Os 10 presos transferidos para a enxovia pertenciam a outros termos da província e apenas um era escravo, o índio Felix da Costa, vindo de Ilhéus. Quanto aos que já estavam na enxovia antes da transferência, havia pelo menos cinco sentenciados a pena de galés: um africano liberto, um branco, dois pardos e um crioulo. Os dois primeiros, condenados por roubo de escravos e o restante, por crime de morte. Apenas o africano liberto, de nome Venâncio, era da capital. ${ }^{57}$

\footnotetext{
${ }^{55}$ OLIVEIRA, op. cit., p. 19.

${ }^{56}$ Carcereiro Antonio Pereira de Almeida ao chefe de polícia, 13.05.1844, APEBa, Cadeias, 1831-1849, maço 6269.

${ }^{57}$ Ibid. Chefe de polícia João Joaquim da Silva ao presidente da província, aditamento ao ofício
} 
A transferência resultou em sérios transtornos para a administração da cadeia. Passadas duas semanas, uma fuga em massa dessa enxovia veio quebrar a rotina da Relação. Na madrugada do dia 6 de junho, alguém avisou ao comandante da guarda que havia um preso na rua, ao lado da cadeia. Imediatamente, o fugitivo foi detido e acabou confessando ter se evadido da enxovia com mais 30 companheiros. A proeza se deu pelo buraco de um cano existente dentro da cela e que estava tampado com uma pedra. Em poucas horas, outros 15 fugitivos foram capturados. O restante do grupo teve mais sorte, pelo menos temporariamente, pois o tal cano tinha dois caminhos, um que desembocava em frente ao local onde o preso foi flagrado, e o outro na rua das Verônicas e na ladeira da Praça, onde a polícia encontrou um buraco aberto, indicando a passagem do restante do grupo. A Cavalaria da $1^{\mathrm{a}}$ Linha e a Artilharia Nacional se uniram com a Guarda Principal para perseguir os fugitivos. ${ }^{58}$ Entre eles estava o escravo Felix da Costa, que mencionei há pouco, o qual foi logo capturado pelo subdelegado da Conceição da Praia, juntamente com outro companheiro de fuga. ${ }^{59} \mathrm{O}$ comandante não deu trégua e, dois dias depois, mais dois presos foram capturados. ${ }^{60} \mathrm{~A}$ última notícia que tive foi que, em 11 de junho, continuavam fugidos 11 presos. ${ }^{61}$

Dentre as formas de resistência prisional, a fuga era a que mais desafiava a administração das cadeias; daí o empenho do comandante em capturar os fugitivos. A desativação da cadeia da Relação já fazia parte dos planos do governo, mas esse episódio parece ter contribuído para que ela fosse definitivamente fechada naquele mesmo ano. Em 1845, seus presos e suas atribuições foram transferidos para o forte do Barbalho que então passou a funcionar como cadeia civil até o ano de $1864 .^{62}$

informando a fuga, 07.06.1845, APEBa, Correspondência recebida da polícia, 1845, maço 3139-3. No primeiro ofício Felix é classificado como pardo e escravo e no segundo como índio e escravo.

${ }^{58}$ Chefe de polícia João Joaquim da Silva ao presidente da província, 07.06.1845, APEBa, Correspondência recebida da polícia, 1845, maço 3139-3.

${ }^{59}$ Chefe de polícia João Joaquim da Silva ao presidente da província, aditamento ao ofício informando a fuga, 07.06.1845, Correspondência recebida da polícia, 1845, maço 3139-3.

${ }^{60}$ Chefe de polícia João Joaquim da Silva ao presidente da província, 09.06.1845, APEBa, Correspondência recebida da polícia, 1845, maço 3139-3.

${ }^{61}$ Chefe de polícia João Joaquim da Silva ao presidente da província, 11.06.1845, APEBa, Correspondência recebida da polícia, 1845, maço 3139-3.

${ }^{62}$ Carcereiro João Caetano Martins ao chefe de polícia, 20.07.1863, APEBa, Relação de presos, 1862-1867, maço 6272; BAHIA. Falla que recitou o presidente da provincia da Bahia, o conse- 
Um ano depois da cadeia do Barbalho substituir a Relação, representantes do Conselho de Salubridade da Província foram examiná-la e o resultado não foi dos melhores. Todas as dez abóbodas que serviam de celas mantinham no mesmo espaço tarimbas e vasos para água e defecções. Além disso, ali estavam "promiscuamente o assassino, o ladrão, o pronunciado, o sentenciado, o detido em custodia, o infractor das disposições policiais, o depositario etc., e com isto, a excepção de segurança, observa-se nellas tudo quanto exprime a idea negativa do artigo 179 parágrafo 21 da Constituição". ${ }^{63}$

Outra cadeia civil que merece destaque é a do Aljube que funcionou de 1833 a 1861. Conforme já vimos, o governo da província realizou reformas no prédio antes de inaugurá-lo como cadeia pública. Uma comissão da Câmara reprovou a reforma, alegando que os engenheiros responsáveis haviam desrespeitado a Constituição ao imitarem "servilmente o mesmo plano das antigas Prisões e mesmo para pior”. ${ }^{64}$ Não ficou claro no que implicava a reprovação, uma vez que a documentação não informa que o Aljube tivesse sido interditado. Ao contrário, ele funcionou com todo vigor por mais de três décadas. Em 1842, foi implantado o primeiro regulamento que o destinou para abrigar os escravos que cometiam infrações policiais. A documentação policial confirma que, durante a existência do Aljube, os escravos eram, preferencialmente, mandados para lá.

Iheiro Antonio Ignacio Azevedo, abertura da Assembléa Legislativa da mesma provincia em 2 de fevereiro de 1847. Bahia: Typ. do Guaycurú de D. Guedes Cabral, 1847, p. 41.

${ }^{63}$ Jornal $O$ Crepusculo, Conselho de Salubridade Pública. Parecer sobre as prisões da fortaleza do Barbalho, ano de 1846, vol. 3, n. 4, p. 51-52.

${ }^{64}$ Pareceres de comissões, op. cit. 


\begin{tabular}{|c|c|c|}
\hline \multicolumn{3}{|c|}{ Quadro 2 - Distribuição dos presos na cadeia do Aljube em 1842} \\
\hline Prisão & Divisão de presos & Descrição das celas \\
\hline $\mathrm{n}^{\circ} 1$ & Escravos pronunciados e sentenciados & $\begin{array}{l}9 \times 6 \text { m de largura e chão de } \\
\text { tijolo }\end{array}$ \\
\hline $\mathrm{n}^{\circ} 2$ & Escravos depositados ou que se encontravam fugidos & $\begin{array}{l}7,5 \times 6 \mathrm{~m} \text { de largura, arejada } \\
\text { e caiada }\end{array}$ \\
\hline$n^{\circ} 3$ & Escravas compreendidas nos dois itens acima & $\begin{array}{l}7 \times 6 \text { de largura, chão de tijolos } \\
\text { e pouco arejada }\end{array}$ \\
\hline$n^{\circ} 4$ & Uso extraordinário & Escura, suja, úmida e de tijolo \\
\hline \multicolumn{3}{|c|}{$\begin{array}{l}\text { Fontes: “Regulamento para a Cadeia da Aljube”, APEBa, Mapa de presos, 1831-1849, maço 6269; Oliveira, op. } \\
\text { cit., p. } 22-23 \text {. }\end{array}$} \\
\hline
\end{tabular}

A cela $n^{\circ} 4$, de "uso extraordinário", era destinada para pessoas detidas em flagrante durante a noite. Se o detido fosse de condição livre, deveria ser transferido, no dia seguinte, para a cadeia da Relação. Na maioria das vezes, os regulamentos não retratavam a realidade; era o cotidiano que os adequava ao funcionamento da instituição. Com o passar dos anos, o aumento da população livre da cidade diversificou o perfil dos presos do Aljube, embora a predominância continuasse sendo de escravos. ${ }^{65}$ No dia 31 de outubro de 1861, o Aljube foi desativado e, a partir de então, a cadeia da Correção passou a ser o principal local de detenção e castigos de escravos.

Ao visitar o forte de Santo Antônio Além do Carmo, localizado na freguesia que leva o seu nome, a comissão de 1829 constatou que o local estava entregue aos cuidados de um comandante militar e sem "prestar utilidade publica”. A comissão observou que o local era "proporcionado para uma boa Casa de Correção”. ${ }^{66}$ Tal recomendação agradou aos vereadores da Câmara que, após algumas reformas, o transformaram numa cadeia pública que passou a funcionar em 1832. A intenção inicial da Câmara era que a fortaleza servisse "interinamen-

\footnotetext{
${ }^{65}$ Relação dos prezos existentes nesta cadeia do Aljube athe 30 de junho de 1854, APEBa, Cadeias, 1850-1854, maço 6270.

${ }^{66}$ Atas e mais objetos da comissão de visita das prisões civis e militares, op. cit., fl. 14v.
} 
te” de penitenciária e abrigasse os sentenciados à pena de prisão com trabalho, atendendo assim a uma das exigências do Código Criminal de $1830 .{ }^{67}$ Essa idéia não se concretizou e a Casa de Correção funcionou como cadeia ordinária - daí a denominação de cadeia da Correção, como ficou conhecida na documentação policial. ${ }^{68}$ Nas décadas de 1830 e 1840 , o seu movimento ainda era tímido em relação às outras cadeias da cidade. Com a desativação do Aljube, em 1861, o movimento da Correção aumentou consideravelmente. Foi também neste ano que a primeira penitenciária da província, a Casa de Prisão com Trabalho, iniciou suas atividades e passou a abrigar grande parte dos sentenciados da província. Logo depois, em 1864, a cadeia do Barbalho também foi desativada, reduzindo o complexo prisional de Salvador à cadeia de Correção e à Casa de Prisão com Trabalho.

Uma questão que não devemos deixar de abordar se refere à população carcerária. Nos relatórios oficiais, como os das comissões da Câmara e do Conselho de Salubridade Pública, como também na tese do dr. Barboza, percebe-se a ausência das reivindicações dos presos que, com certeza, não ficaram passivos durante as visitas. Infelizmente, esta é uma característica da documentação oficial. Contudo, existem outros tipos de documentos que revelam de forma mais explícita a participação dos presos nos seus próprios mecanismos de dominação pelo Estado. ${ }^{69}$ Independentemente do tipo de instituição, cadeia ou penitenciária, os presos estavam longe de aceitar passivamente o tratamento prisional sem protestar contra a injustiça, a violência, a má alimentação, a falta de tratamento médico, a privação das visitas etc. A escrita era um meio muito utilizado por eles. Através de cartas individuais ou coletivas, os presos faziam com que as suas reivindicações chegassem às autoridades e, sem dúvida, este era um meio eficaz de tornar público o que, de outro modo, se encerraria dentro dos muros da prisão. Porém, existiam outros meios de protestos. Na medida em

\footnotetext{
${ }^{67} \mathrm{O}$ artigo 46 do Código Criminal estipulou que a pena de prisão com trabalho deveria ser cumprida dentro das prisões.

${ }^{68}$ De “cadeia” também eram chamadas o Aljube, a Relação e o Barbalho. Já a Casa de Prisão com Trabalho era denominada de prisão ou penitenciária, nunca de cadeia. Nas primeiras décadas do século XX, a Casa de Correção passou a chamar-se Casa de Detenção. Quanto à Casa de Correção do Santo Antonio servir, interinamente, para condenados a pena de prisão com trabalho, ver APEBa, Câmara de Salvador, 1845-1846, maço 1399.

${ }^{69}$ Sobre a discussão da participação das classes menos favorecidas nos processos de dominação pelo Estado ver IGNATIEFF, Michael. Instituições totais e classes trabalhadoras: um balanço crítico. Revista Brasileira de História. São Paulo, nº 14, 1987, p. 193.
} 
que as tentativas de negociação se esgotavam ou se, por algum motivo, essa negociação nem tivesse existido, os presos reagiam de outras formas, através das fugas, das revoltas, das brigas, da insubordinação, enfim, de confrontos diretos que, normalmente, resultavam em represálias da administração ou do próprio chefe de polícia. Neste caso, as punições vinham em forma de violência corporal, reclusão em solitárias, privação das visitas etc. Não é por acaso que a documentação demonstra a preferência dos presos por meios indiretos de enfrentamento, como o uso da escrita, das simulações de doenças, do "bom comportamento", ou de outros tipos de negociações. ${ }^{70}$

A vida diária da prisão era construída a partir de relações complexas em que os presos absorviam as normas oficiais, reinterpretavam-nas e as utilizavam a seu favor. Sendo assim, não devemos atribuir somente às classes dirigentes a tentativa de melhorar as prisões. Os presos lutaram contra o sistema opressor, sendo eles os principais responsáveis para que os regulamentos das prisões não fossem seguidos na sua totalidade. Dessa maneira, eles provocavam um clima de desordem nas cadeias que, de certo modo, também estimulou o governo a melhorar o aparelho prisional, até mesmo como forma de legitimação do poder. Seria um equívoco reducionista acreditar que a lei representa apenas o poder da classe dominante. Se assim fosse não seria necessário o historiador estudá-la, pois as questões já estariam resolvidas. ${ }^{71}$

Procurei até agora apresentar a organização do sistema prisional entre os anos de 1829 e início da década de 1860, período em que, paralelamente, os debates e a construção da Casa de Prisão com Trabalho estavam também acontecendo. Tal contextualização é imprescindível para entendermos, de fato, como se deu a reforma prisional baiana que não se resumiu apenas à construção de uma penitenciária. Contudo, acredito ser pertinente contextualizar também a legislação brasileira, bem como os modelos estrangeiros de sistema penitenciário para, finalmente, falarmos da implantação da Casa de Prisão com Trabalho.

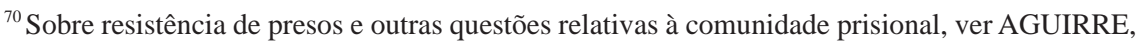
Carlos. The criminals of Lima and their worlds: the prison experience, 1850-1935. Durham: Duke University Press, 2005.

${ }^{71}$ Ver a este respeito THOMPSON, E. P. Senhores e caçadores. Rio de Janeiro: Paz e Terra, 1987, p. 358-359.
} 


\section{A legislação e a reforma prisional}

Diferentemente do que muitos acreditam, a reforma prisional no Brasil não teve início com a Constituição do Império em 1824. Alguns acontecimentos anteriores indicam que esse movimento começou até mesmo antes da independência do Brasil. Em 1821, Cipriano Barata foi eleito deputado em Salvador e, ao lado de outros deputados brasileiros, seguiu para a Europa onde atuou como relator da comissão sobre os negócios do Brasil nas Cortes de Lisboa. Entre os seus projetos, um deles, apresentado na sessão de 7 de fevereiro de 1822 , reivindicava mudanças no aparelho prisional do Brasil. No seu pronunciamento, pediu que a prisão do forte de São Pedro e a “infernal masmorra” do forte do Mar fossem interditadas e os objetos de torturas destruídos. Solicitou que essa ordem fosse imediatamente enviada para a Bahia de Todos os Santos e para o resto do Brasil onde existissem prisões deste tipo. ${ }^{72}$ Como vimos anteriormente, Cipriano Barata foi um grande conhecedor dos cárceres coloniais. Em 1823, descreveu, no jornal Sentinela da Liberdade, a terrível experiência que viveu nas masmorras das fortalezas. Citou as torturas, os gritos de dor dos prisioneiros, a convivência com ratos e insetos e o reaproveitamento das "roupas dos enforcados servindo como fronha". ${ }^{73}$

Holloway, no seu estudo sobre a polícia no Rio de Janeiro, também destacou esse início da década de 1820 como sendo importante para as mudanças que estavam por acontecer: "em maio de 1821, menos de um mês depois de assumir a regência, d. Pedro deu o primeiro passo para regulamentar as práticas policiais e judiciais". ${ }^{74}$ Outro autor que também destacou esses acontecimentos foi Edmundo Campos Coelho, informando que os constituintes brasileiros enviaram uma comissão a d. Pedro para que este aprovasse medidas contra o caos da jurisprudência portuguesa na colônia com relação à administração da Justiça. Dentre essas medidas estava aquela que Holloway considerou como um primeiro passo rumo à reforma prisional e criminal, ou seja, a aprovação da Lei de 1821 que garantia os direitos individuais contra a arbitrariedade dos juízes criminais no Brasil. ${ }^{75}$

\footnotetext{
${ }^{72}$ MOREL, op. cit., p. 125.

${ }^{73}$ Jornal Sentinela da Liberdade na Guarita de Pernambuco n ${ }^{\circ}$ 17, 1823, apud MOREL, op. cit., p. 82.

${ }^{74}$ HOLLOWAY, op. cit., p. 56.

${ }^{75}$ Eis algumas das medidas aprovadas por d. Pedro na Carta da Lei de 23 de maio de 1821: “ $1^{\circ}$ ) Que desde sua data em diante nenhuma pessoa livre no Brasil possa jamais ser presa sem ordem por escrito do juiz ou magistratura criminal do território exceto somente o caso de flagrante delito,
} 
A Constituição do Império, de 1824, e o Código Criminal, de 1830, pouco acrescentaram aos direitos individuais, além daqueles já estabelecidos nas medidas de 1821. O mesmo ocorreu com relação às cadeias. A Constituição apenas incorporou o que já havia sido determinado pela referida lei, ou seja, a construção de cadeias mais arejadas, limpas, com várias celas, visando separar os réus conforme a natureza de seus crimes. Ficou também estabelecido que fosse elaborado o quanto antes um Código Criminal que viesse a substituir o Livro V das Ordenações Filipinas. A Constituição aboliu as penas corporais, “os açoites, a tortura, a marca de ferro quente, e todas as mais penas cruéis”. Essas proibições não se aplicaram todas elas aos escravos, pois o Código Criminal de 1830 reservou para eles o artigo 60, que previa punição com açoites e, em alguns casos, galés e pena de morte: "Art. 60. Si o réo for escravo, e incorrer em pena que não seja a capital ou de galés, será condemnado na de açoutes, e, depois de os soffrer, será entregue a seu senhor, que se obrigará a traze-lo com um ferro, pelo tempo e maneira que o juiz designar”. ${ }^{76}$

Provavelmente referindo-se a este artigo, um reformador francês fez o seguinte comentário: “A pena de morte, e os açoites, eis ahi todo o código penal dos escravos". ${ }^{77}$ A desigualdade da legislação criminal acentuou-se ainda mais com o passar dos anos. Por exemplo, a Lei Imperial, de 10 de junho de 1835,

em que qualquer do povo pode prender o delinquente. $2^{\circ}$ ) Que nenhum juiz ou magistrado criminal possa expedir ordem de prisão sem proceder culpa formada por inquirição sumária de três testemunhas, duas das quais jurem contestes, assim o fato em lei expressa seja declarado culposo, como a designação individual do culpado [...]. $3^{\circ}$ ) Que quando se acharem presos os que assim forem indiciados criminosos, se lhes faça imediatamente e sucessivamente o processo, que deve findar dentro de quarenta e oito horas peremptórias, improrrogáveis, e contadas no momento da prisão [...]. $4^{\circ}$ ) Que em caso nenhum, possa alguém ser lançado em segredo ou masmorra estreita, escura, ou infecta, pois a prisão deve só servir para guardar as pessoas e nunca as adoecer e flagelar; ficando implicitamente abolido para sempre o uso de correntes, algemas, grilhões e outros quaisquer ferros inventados para martirizar homens ainda não julgados a sofrer qualquer pena aflitiva por sentença final; entendendo-se, todavia, que os juízes e magistrados criminais poderão conservar por algum tempo, em casos gravíssimos, incomunicáveis os delinquentes, contanto que seja em casas arejadas e cômodas e nunca manietados ou sofrendo qualquer espécie de tormento [...]”.COELHO, Edmundo Campos. As profissões imperiais: medicina, engenharia e advocacia no Rio de Janeiro 1822-1930. Rio de Janeiro: Record, 1999, p. 155-157.

${ }^{76}$ FILGUEIRAS JUNIOR, op. cit., p. 48.

${ }^{77}$ Systema penitenciario, Relatório, Feito em nome da commissão encarregada, pelo Exellentissimo senhor Presidente da Provincia, de examinar as questões relativas a Casa de Prisão com Trabalho, da Bahia. Salvador: Typographia de Galdino Joze Bizerra, e Companhia, 1847, p. 51. Biblioteca do Mosteiro de São Bento (doravante BMSB), obras raras. Agradeço ao professor João Reis pela localização deste documento. 
previa uma série de punições agravantes para delitos cometidos por escravos, tirando-lhes o direito dos recursos processuais ordinários. Se o escravo matasse ou ferisse gravemente o seu senhor, o administrador, o feitor ou qualquer pessoa de suas famílias, ele seria condenado à morte sem direito a apelação. A mesma pena era aplicada aos cabeças de insurreição, mas, neste caso, era possível recorrer da sentença. O escravo seria punido com açoites em caso de ferimentos leves, e o número de açoites seria relativo ao grau da agressão. ${ }^{78}$ Essa lei significou mais uma das muitas medidas tomadas pelas autoridades que temiam a repetição de episódios como a rebelião baiana de 1835 , conhecida como revolta dos malês. ${ }^{79}$ Diferente da Constituição, a legislação criminal não se acanhou em legalizar o tratamento desigual da Justiça perante o escravo.

De um modo geral, as penas estabelecidas pelo novo Código eram de morte, galés, prisão simples, prisão com trabalho, banimento, degredo, desterro para dentro do país, multa, suspensão ou perda de emprego, no caso de funcionários públicos, e açoites para os escravos. Para a maioria dos delitos prevaleceu a pena de prisão com trabalho que deveria ser cumprida em prisões especialmente destinadas para esse fim. Porém, como já mencionado, o artigo 60 fazia com que a pena de prisão com trabalho não fosse aplicada aos escravos, para que fossem preservados interesses dos senhores. As prisões especialmente destinadas para o cumprimento das penas de prisão com trabalho de que trata o Código Criminal eram as penitenciárias, chamadas de Casa de Correção e Casa de Prisão com Trabalho. O Código nada estabeleceu sobre as regras de funcionamento dessas instituições; somente com a reforma do Código de Processo Criminal, em 1841, estas questões ficaram mais definidas. ${ }^{80}$ De qualquer forma, a construção das penitenciárias foi o principal símbolo da reforma prisional brasileira.

Em 1833, o ministro da Justiça, Honório Hermeto Carneiro Leão, informava sobre o andamento das construções das casas de correção no Brasil: "Não exis-

\footnotetext{
$\overline{{ }^{78} \text { BRASIL. Lei de } 10}$ de junho de 1835, FILGUEIRAS JUNIOR, op. cit., p. 321. Ver também os Avisos complementares a essa lei que ajustavam os seus artigos de acordo com os casos que iam surgindo e até mesmo tentavam enquadrar certos tipos de delitos dentro desta lei. Por exemplo: “Tendo-se dado em S. Paulo o facto de uns escravos matarem á sua senhora, que por escriptura publica lhes havia dado a liberdade para gozarem depois da morte della, o Trib. da Relação dessa província por Acc. de 24 de Junho de 1874, App. 18, decidio que havião os réos incorrido no art $1^{\circ}$ da Lei de 10 de Junho de 1835, [assassinato do senhor] visto que erão de condição escrava quando praticarão o crime de que forão accusados". FILGUEIRAS JUNIOR, op. cit., p. 321.

${ }^{79}$ Sobre o levante dos malês, ver REIS, 2003, op. cit., p. 511.

${ }^{80}$ A Lei Imperial $n^{\circ} 261$, de 3 de dezembro de 1841, reformou o Código do Processo Criminal e foi complementada pelos regulamentos $\mathrm{n}^{\circ} \mathrm{s} 120,122$ e 147 de 1842 .
} 
tem ainda no Império Casas destinadas para prisão com trabalho; verdade he que na Lei do orçamento do corrente ano financeiro forão decretadas quantias para esse fim; não estou porem informado da aplicação, que nas Províncias se tem dado a essas quantias". ${ }^{81}$ A lei do orçamento a que se referiu o ministro era a lei imperial orçamentária de 15 de novembro de 1831 que disponibilizou verbas para a construção de penitenciárias em todo o Império. Para isso, as províncias deveriam fazer uso do dinheiro entre o mês de julho de $1832 \mathrm{e}$ junho de $1833 .{ }^{82} \mathrm{~A}$ Bahia aplicou a sua verba em abril de 1833 , dando início à construção da Casa de Prisão com Trabalho.

Não foram todas as províncias que construíram casas de correção. Algumas adaptaram oficinas de ofício nas cadeias já existentes, enquanto outras construíram prédios novos. A província do Rio de Janeiro iniciou a construção da sua Casa de Correção em 1834, inaugurando-a em 1850; a província de São Paulo deu início a sua obra em 1838 e, no ano de 1852, começou a receber presos. Já a província do Rio Grande do Sul construiu oficinas na cadeia civil da capital ou Cadeia de Justiça, como também era chamada, e somente a partir de 1896 recebeu oficialmente a denominação de Casa de Correção. A Bahia iniciou a sua obra em 1833 e deu início às atividades em 1861, inaugurando-a oficialmente em $1863 .^{83}$

Diferentemente das outras províncias, a Bahia chamou oficialmente a sua instituição penitenciária de Casa de Prisão com Trabalho, embora a denominação Casa de Correção fosse utilizada pelos engenheiros além de ser citada em almanaques da época como, por exemplo, o de $1845 .{ }^{84}$ Provavelmente, a escolha do nome oficial fosse devida ao fato da lei orçamentária de 1831, já citada anteriormente, especificar que a verba seria destinada à construção de

\footnotetext{
${ }^{81}$ BRASIL. Relatório da Repartição dos negócios da justiça apresentado a Assembléia Legislativa na seção ordinária de 1833 pelo respectivo ministro e secretário de Estado Honório Hermeto Carneiro Leão. Rio de Janeiro: Typographia Nacional, 1833.

${ }^{82}$ BRASIL. Lei de 15 de novembro de 1831 , Orça a receita e fixa a despeza para o ano financeiro de 1832-1833. Título II, capítulo 3, artigo 28, § 11. Diario Oficial do Estado da Bahia, Edição Especial do Centenário, 1923, p. 515-517.

${ }^{83}$ Sobre o Rio de Janeiro, ver PESSOA, Gláucia Tomaz de Aquino. Trabalho e resistência na penitenciária da Corte, 1850-1876. Dissertação de mestrado em História, Universidade Federal Fluminense, Rio de Janeiro, 2000; para São Paulo, ver SALLA, op. cit., p. 46; sobre Porto Alegre, ver PAIVA, Helena Marisa Vianna. A Casa de Correção de Porto Alegre, 1889-1898. Dissertação de mestrado em História, Universidade Católica do Rio Grande do Sul, Porto Alegre, 2002, p. 5, 59. ${ }^{84}$ Almanaque civil político e comercial da Cidade da Bahia para o ano de 1845. Edição fac-similar, Salvador: Fundação Cultural, 1998, p. 255.
} 
uma "Casa de Prisão com Trabalho”, sugerindo assim o nome para o então presidente da província. Uma comissão de estudiosos que examinou as questões penitenciárias da Bahia em 1847 atribuiu a esta mesma lei o motivo da escolha do nome de Casa de Prisão com Trabalho. Outra possibilidade seria de já existir na cidade uma cadeia comum chamada Casa de Correção, localizada no forte Santo Antônio Além do Carmo, não cabendo assim atribuir o mesmo nome para a penitenciária. ${ }^{85}$

O novo Código Criminal, conforme observou Holloway, "especificava princípios estabelecidos pela Constituição de 1824, concretizando assim um dos principais objetivos dos reformadores liberais”; porém, a realidade do aparelho da Justiça não dava condições de atender à legislação, ${ }^{86}$ a começar pela falta de instituições para o cumprimento da pena de prisão com trabalho. Neste caso, quando o preso era condenado a esta pena e na província não existisse uma casa de correção, passava a vigorar o artigo 49 do Código Criminal que tinha a seguinte redação: “enquanto se não estabelecerem as prisões com as commodidades e arranjos necessarios para o trabalho dos reos, as penas de prisão com trabalho serão substituídas pelas de prisão simples, accrescentando-se em tal caso a esta mais a sexta parte do tempo por que aquellas deverião impôr-se". ${ }^{87}$

A nova legislação criminal gerou muita polêmica. O ministro da Justiça, Carneiro Leão, por exemplo, posicionou-se contra a pena de prisão com trabalho: “O Código Criminal não faz quase nenhum uso das penas de morte, galés, degredo, e desterro; a maior parte dos delitos tem a pena de prisão com trabalho, e entretanto não existe no Império huma só Casa para esse fim!!"” ${ }^{88} \mathrm{O}$ ministro também reprovou o artigo 49, citado acima, justificando que os condenados iriam superlotar as cadeias, resultando em risco para a manutenção da ordem interna, além de fazer com que presos condenados permanecessem misturados com presos não condenados. Propôs ainda que o Código Criminal substituísse a pena de prisão com trabalho por outro tipo de pena, como degredo, galés e de morte.

Para o ministro, a eficácia das instituições penitenciárias dos Estados Unidos e da Europa estava muito distante da realidade do Brasil. Ele era a favor que se fizesse mais uso da pena de degredo, porém aplicada de forma diferente daquela

\footnotetext{
${ }^{85}$ Systema penitenciario, op. cit., p. 55.

${ }^{86}$ HOLLOWAY, op. cit., p. 67.

${ }^{87}$ FILGUEIRAS JUNIOR, op. cit., p. 36-37.

${ }^{88}$ BRASIL. Relatório da Repartição dos negócios da justiça apresentado a Assembléia Legislativa na seção ordinária de 1833, op. cit., p. 29.
} 
prevista no Código Criminal. Sua idéia era criar colônias agrícolas para os degredados trabalharem na agricultura "debaixo de uma rigorosa administração". Ainda, segundo o ministro, esse tipo de colônia estaria dando ótimos resultados na Bélgica e na Holanda: “Ahi, alem das Colônias agrícolas forçadas para onde são enviados os condemnados, outras se instituirão, onde são recebidos voluntariamente os indivíduos, que sem esse asilo se entregarião á mendicidade, e á vadiação nas grandes Cidades [...]" . ${ }^{89}$ Este era um pensamento comum entre os políticos daquela época, que acreditavam que as colônias agrícolas solucionariam o problema da mendicância nas cidades. ${ }^{90}$ As sugestões do ministro de alterar o Código não foram atendidas; tampouco o sistema de colônias agrícolas obteve êxito no Império.

Como vimos, o Brasil independente continuou escravista e aristocrático, o que significa dizer que as instituições e todo o processo de construção de um novo Estado nacional precisaram se adaptar a essa realidade social, política e econômica. Conforme observou Salvatore, a "brutalidade e os espetáculos sangrentos teriam sido eliminados apenas para o homem livre, continuando para os escravos". ${ }^{91}$ Sendo assim, a nova legislação brasileira, inspirada nas idéias liberais, foi estrategicamente elaborada pelos legisladores visando atender a essa demanda. Especificamente falando da reforma prisional, esta pretendia organizar o complexo carcerário a fim de proporcionar condições para que as penas previstas no Código Criminal pudessem ser efetivamente cumpridas, sem que leis constitucionais fossem violadas. Tão importante quanto construir penitenciárias para o cumprimento da pena de prisão com trabalho, era também organizar as cadeias para receber os sentenciados às penas de galés e de açoites - neste caso, me refiro aos escravos. Contudo, veremos mais adiante as dificuldades que os reformadores baianos encontraram para adaptar a Casa de Prisão com Trabalho à legislação criminal brasileira e especificamente ao contexto baiano.

\footnotetext{
${ }^{89}$ Ibid., p. 30-31.

${ }^{90}$ FRAGA FILHO, op. cit., p. 169-178. Neste capítulo o autor aborda a fundação do Asilo de Mendicidade de Salvador.

${ }^{91}$ SALVATORE, Ricardo, Penitentiares, visions of class, and export economies. In: SALVATORE, Ricardo e AGUIRRE, Carlos (orgs.). The birth of the penitentiary in Latin America: Essays on criminology, prison reform, and social control, 1830-1940. Austin: University of Texas Press, 1996, p. 200.
} 


\section{Os modelos penitenciários estrangeiros}

Na Bahia oitocentista quase nada se produzia intelectualmente sem a influência das idéias estrangeiras, as quais, porém, sofriam adaptação à realidade local. Assim ocorreu com a reforma prisional, quando o Brasil aderiu ao movimento de modernização das prisões, que teve início na Inglaterra e nos Estados Unidos no final do século XVIII. ${ }^{92}$ As execuções e as torturas em praças públicas, utilizadas para atemorizar quem estivesse planejando novos crimes, foram gradativamente abandonadas pelos países do Ocidente, entrando em cena a penalidade moderna que privava o criminoso do seu bem maior - a liberdade - internando-o numa instituição construída especificamente para recuperá-lo, que recebeu o nome de penitenciária. O seu funcionamento era regido por normas que seriam aplicadas de acordo com o modelo penitenciário escolhido que utilizava elementos como o trabalho, a religião, a disciplina, o uso de uniformes e, sobretudo, o isolamento como método de punição e recuperação do condenado. Dessa forma, esperava-se criar um "novo homem” que seria devolvido à sociedade com todos os atributos necessários à convivência social, principalmente para o trabalho.

Dois sistemas rivais norte-americanos - Auburn e Pensilvânia - dividiram reformadores de várias partes do mundo. Muitos países enviaram representantes para conhecer as experiências norte-americanas, no intuito de adotá-las. Essas visitas resultaram em relatórios que se transformaram em valiosas fontes históricas. Entre os mais conhecidos estão os escritos dos franceses Alexis de Tocqueville e Gustave de Beaumont. ${ }^{93}$ Eles eram defensores do sistema penitenciário conhecido como Pensilvânia, que previa o isolamento contínuo do condenado, ou seja, todas as suas atividades deveriam ser realizadas em completa solidão, incluindo o trabalho. Esse sistema foi repudiado por muitos juristas e médicos que acreditavam que o isolamento total levaria o condenado

\footnotetext{
${ }^{92}$ Sobre a reforma prisional nos Estados Unidos, ver ROTHMAN, David J. Perfecting the prison: United States, 1789-1865. In: MORRIS, Norval; ROTHMAN, David J (orgs.). The Oxford history of the prison. New York: Oxford University Press, 1995, p. 100-116.; sobre a Inglaterra, ver MCGOWEN Randall. The well-ordered prison: England, 1780-1865. In MORRIS; ROTHMAN (orgs.), op. cit., p. 79-109; sobre a França, ver PERROT, 2001, op. cit., p. 235-332, FOUCAULT, Michel. Vigiar e punir: História da violência nas prisões. $5^{\text {a }}$ edição. Petrópolis: Vozes, 1987, entre outros.

${ }^{93}$ BEAUMONT, Gustave de; TOCQUEVILLE, Alexis de. Du système pénitentiaire aux ÉtatsUnis et de son application en France, suivi d'un appendice sur les colonies pénales et de notes statistiques, 2 vols. Paris: Impr. de H. Fournier, 1833, 2e éd., Paris: C. Gosselin, 1836.
} 
à loucura ou à morte. No sistema rival, conhecido por Auburn, ou silent system, as atividades eram coletivas e o trabalho realizado em oficinas de ofício no mais absoluto silêncio. Era o que eles chamavam de separação moral já que, fisicamente, estavam reunidos. À noite, eram acomodados em celas individuais. Por volta da década de 1820, as primeiras penitenciárias dos Estados Unidos a adotarem este sistema utilizavam castigos corporais para punir os infratores do silêncio, razão que levou muitos reformadores a defenderem o outro sistema. Porém, algum tempo depois, os castigos corporais foram substituídos por outras formas de punição, como o uso da solitária e a redução alimentar que muitas vezes se resumia a pão e água.

A Igreja foi a principal inspiração dos sistemas penitenciários que se espalharam pelo mundo ocidental no século XIX. A palavra penitenciária tem suas origens nas formas e punição do clero desde a Idade Média. Um dicionário do século XIX a definiu como "tribunal da Cúria Romana em que se concedem dispensas e absolvições em nome do papa”. Penitência como “castigo, punição, arrependimento". Penitenciário como "o cardeal que preside a penitenciária, o eclesiástico que impõe penitência, e absolve de casos reservados”. ${ }^{94}$ Michelle Perrot, embora não tenha se aprofundado na questão, mencionou a influência das experiências italianas, durante o papado de Clemente XI, na construção do pensamento penitenciário. ${ }^{95}$ Este papa aplicou, pela primeira vez, as idéias do monge Mabillon que escreveu uma obra intitulada Reflexões sobre as prisões monásticas, publicada em 1695, em que criticava as prisões da Igreja e propunha um regime em que o trabalho, os cuidados com a higiene e outras atividades compusessem as normas disciplinares. ${ }^{96}$ Clemente XI aprovou essas novas idéias e, com a criação do reformatório de São Miguel, as prisões religiosas em Roma passaram a adotar o isolamento noturno e, durante o dia, as orações e outras atividades laborais passaram a ser realizadas coletivamente. ${ }^{97}$ Esse regime,

\footnotetext{
${ }^{94}$ CONSTANCIO. Francisco Solano. Novo dicionário da língua portuguesa. Duodécima edição. Paris: E. Belhotte, livreiro de S. M. El-Rei de Portugal, 1884, p. 761. Ver FOUCAULT, Michel. Os anormais: curso no Collège de France (1974-1975). Tradução de Eduardo Brandão. São Paulo: Martins Fontes, 2001, p. 216.

${ }^{95}$ PERROT, 2001, op. cit., p. 262.

${ }^{96}$ LEAL, César Barros. Prisão: crepúsculo de uma era. $2^{\text {a }}$ edição revista e atualizada. Belo Horizonte: Del Rey Editora, 2001, p. 33-34.

${ }^{97}$ SHELDEN, Randall G. Arquitetural and disciplinary ideals in the earliest prisions. Arquitetural and Disciplinary I. Disponível em: http://www.sheldensays.com/architectural_and_disciplinary_i. $\mathrm{htm}$. Acesso em 11/06/2006.
} 
muito semelhante àquele que viria a ser chamado de sistema de Auburn, na década de 1820, já funcionava desde 1773 na penitenciária de Gand, na Bélgica. Esta prisão foi a principal referência de Pedro Weyll, engenheiro que traçou o primeiro projeto da Casa de Prisão com Trabalho da Bahia. ${ }^{98}$ Contudo, os Estados Unidos foram a principal referência mundial nas questões penitenciárias, seguidos da Inglaterra e da França.

Na Inglaterra, o trabalho como elemento regenerador já era discutido deste o final do século XVI, época em que foram construídas as workhouses ou houses of correction, instituições que tinham por objetivo afastar das ruas a crescente população de mendigos e instrumentalizá-los para o trabalho. Segundo McGowen, no início do século XVII já existiam cerca de 170 casas de correção distribuídas pela Inglaterra. O modelo dessas instituições teria sido aproveitado nos mínimos detalhes pela legislação inglesa de 1780 que previa a reforma das prisões. John Howard (1720-1790), um renomado reformador, foi destaque na Inglaterra por ter dedicado toda sua vida à causa das prisões. Howard viajava por todo o país para conhecer de perto as condições dos cárceres. ${ }^{99}$

Outra importante participação da Inglaterra para as discussões penitenciárias foi o modelo do panóptico, desenvolvido por Jeremy Bentham. Nascido em Londres, em 1748, Bentham estudou Direito, tornou-se um penalista e, com a ajuda do irmão, o engenheiro Samuel Bentham, escreveu $O$ panóptico, fruto de mais de vinte anos de estudos. "Foi meu irmão quem primeiro me deu a idéia da arquitetura de minha prisão”, escreveu Bentham. ${ }^{100} \mathrm{O}$ panóptico não consistia apenas numa arquitetura; era toda uma ideologia de controle social, que podia ser empregada nas escolas, hospitais, prisões e quartéis, ou seja, uma idéia destinada a instrumentalizar o poder nas instituições de controle social. Quando foi publicado O panóptico, em 1786, os debates sobre a reforma prisional na Inglaterra estavam no áuge. Porém, neste período, os reformadores não concordavam com a vigilância central proposta na arquitetura de Bentham e, além disso, sua obsessão muitas vezes foi confundida com loucura. Bentham era contra o trabalho como forma de punição. "O pavor de uma prisão não deve prevalecer sobre a idéia do trabalho”. Tampouco aprovava o sistema celular

\footnotetext{
${ }_{98}$ Jornal O Musaico, set/out de 1847, p. 286-289.

${ }^{99}$ Sobre o assunto, ver MCGOWEN, op. cit., p. 79-109.

${ }^{100}$ REYBAUD Louis. Éstudes sur les réformateurs sociaux, p. 249, apud PERROT, Michelle. O inspetor Bentham. In: SILVA, Tomaz Tadeu da. (org.). Jeremy Bentham, o panótico. Belo Horizonte: Autêntica, 2000, p. 122.
} 
de isolamento contínuo, ou sistema da Pensilvânia, que, naquela altura, era o preferido pelos reformadores. "É um castigo que pode ser útil durante alguns dias para reprimir um espírito de rebelião, mas não se deve prolongá-lo”. ${ }^{101}$

A maioria das prisões da Europa construídas a partir do modelo panóptico não seguiu totalmente a arquitetura proposta por Bentham. Da mesma forma, as penitenciárias da Corte, de São Paulo e da Bahia tiveram seu projeto arquitetônico baseado no modelo do panóptico. No entanto, nenhuma delas foi finalizada de acordo com o plano inicial. Segundo Simon Werret, muitos críticos de Bentham concordam "com a idéia de que o Panóptico constituiu - ou ajudou a constituir - uma nova forma de poder no final do século XVIII". ${ }^{102}$ Para Foucault, o panóptico foi um sonho de Bentham que se realizou não necessariamente na sua forma arquitetural, mas como "uma definição das formas de exercício do poder". ${ }^{103}$

Os dois sistemas - Auburn e Pensilvânia - dividiram as opiniões dos reformadores estrangeiros tanto quanto dos reformadores baianos. Entre os defensores do sistema da Pensilvânia estava o governador do Estado da Califórnia, John Fremont, um dos responsáveis pela compra da Ilha de Alcatraz, em 1847, onde foi construída a conhecida prisão que levou o mesmo nome. Segundo Fremont, o isolamento total era o melhor dos sistemas, pois "não seria justo que um homem honrado que por um erro da justiça é atirado à prisão fique arriscado a encontrar mais tarde um miserável que o trate como igual”. ${ }^{104}$ Os reformadores Alex Tocqueville e Gustave de Beaumont acreditavam que o sistema da Pensilvânia "produzia homens mais honestos enquanto que o sistema de Auburn produzia cidadãos mais obedientes”. ${ }^{105}$ Eles se referiam aos efeitos dos severos castigos utilizados para manter o silêncio no sistema de Auburn.

\footnotetext{
${ }^{101}$ Ibid., 130.

${ }^{102}$ Ibid., p. 154, grifo do autor.

${ }^{103}$ FOUCAULT, Michel. Prisões e revoltas nas prisões. In: MOTA, Manoel Barros da (org). Michel Foucault, estratégia, poder-saber. Rio de Janeiro: Forense Universitária, 2003, p. 72.

${ }^{104}$ SEIXAS, Eustaquio Primo de. Considerações sobre o systema penitenciario adoptado pelo Codigo Penal vigente. These apresentada ao concurso para preenchimento de uma vaga aberta no Tribunal de Appellação e Revista do Estado da Bahia em 25 de Outubro de 1897. Bahia: Typographia e Encadernação do Diario da Bahia, 1897, p. 29.

${ }^{105}$ ROTHMAN. Perfecting, op. cit., p. 124. A discussão sobre o trabalho penal feita por Tocqueville e Beaumont foi estudada por SALLA, Fernando. Os escritos de Alexis de Tocqueville e Gustave de Beaumont sobre a prisão: o problema da participação dos negócios privados. Revista Plural. São Paulo: USP, v. 1, n. 1, 1994, p. 1-16.
} 
Em contrapartida, os simpatizantes do sistema de Auburn alegavam que o isolamento total era contra a natureza humana, além de ser responsável pelos suicídios e pelos casos de alienação mental, tornando esse sistema anticristão. Charles Lucas, o mais conhecido reformador francês, foi um árduo defensor do sistema de Auburn. Num discurso aos representantes da Assembléia Legislativa de Louisiania, o liberal francês François Mignet fez o seguinte pronunciamento contra o sistema da Pensilvânia:

Esses condemnados encerrados por toda a vida em um espaço estreito, mortos para o mundo ao qual não podem voltar, porque o direito de graça não se exerce em seu favor; estranhos à família; submettidos periodicamente durante muitos mezes a uma inteira solidão e a uma desoladora inacção; nunca podendo respirar um ar puro, nem ver um raio do sol; enterrados em uma cellula como em um tumulo sobre o qual se lê já seu epitaphio, não são punidos mais cruelmente do que os outros que não estão sujeitos a estas terriveis condições? Não é para temer que sua razão succumba, que sua alma, que se quer salvar, chegue ao desespero? Se não é permittido matar o corpo, não se pode com maioria de razão matar a intelligencia; antes ser defuncto do que louco. ${ }^{106}$

Segundo Michelle Perrot, até 1844 a preferência dos franceses foi, de um modo geral, pelo sistema de Auburn. Depois disso foi aprovado um projeto-lei que estabeleceu o sistema da Pensilvânia para todas as penitenciárias da França. ${ }^{107}$

\section{A implantação da Casa de Prisão com Trabalho da Bahia}

Agora que temos uma visão mais ampla do contexto prisional baiano, assim como das características dos modelos estrangeiros, passo finalmente a expor os principais aspectos do processo de implantação da Casa de Prisão com Trabalho. Em 1833, a Câmara Municipal de Salvador, ao invés da fortaleza do Barbalho ou da Casa Velha da Pólvora, preferiu escolher como local da futura penitenciária uma área pantanosa que correspondia a "100 braças quadradas"

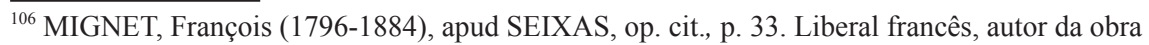
MIGNET, F.A.M. History of the French Revolution from 1789 to 1814, (1824). London: G. Bell and Sons, Ltd., 1912.

${ }^{107}$ PERROT, 2001, op. cit., p. 235-332. O pensamento de Charles Lucas foi analisado por FOUCAULT, op. cit., 1987, principalmente na quarta parte, capítulo I.
} 
localizada "na marinha fronteira ao Engenho da Conceição, pelos fundos da Capela dos Mares”. ${ }^{108}$ Este local pertencia à freguesia da Nossa Senhora da Penha de França de Itapagipe, periferia da cidade de Salvador. ${ }^{109}$ Em novembro daquele mesmo ano, o presidente da Câmara recebeu das mãos do arquiteto Pedro Weyll a planta da instituição que foi aprovada pelos vereadores. ${ }^{110} \mathrm{Em}$ janeiro de 1834, a obra teve início e Weyll foi contratado para dirigi-la. O projeto arquitetônico foi inspirado na penitenciária de Gand, na Bélgica, e o sistema escolhido foi o de Auburn, o mesmo adotado naquela prisão. A planta previa um edifício panóptico octogonal, dividido em oito raios, com uma casa central e com capacidade para oitocentos presos. Tinha "296 braças de circuito", o que corresponde a 541 metros. Um projeto gigantesco para a época.

Com o Ato Adicional de 1834, o governo provincial assumiu a responsabilidade da construção, apesar da discordância quanto ao projeto inicial dos vereadores da Câmara. Durante os quase trinta anos de construção, as autoridades não conseguiram chegar a um consenso em relação ao prédio ou às correlatas doutrinas penitenciárias. A indecisão sobre qual sistema penitenciário seguir - Auburn ou Pensilvânia - comprometeu o edifício que ficou reduzido a dois raios e, ainda assim, com sérios problemas na sua arquitetura, pois o projeto arquitetônico deveria estar em harmonia com um ou outro sistema, uma vez que cada um exigia soluções físicas diferentes.

Até os primeiros anos da década de 1840, a obra caminhou lentamente e sem grandes novidades, até a chegada do presidente Francisco José de Souza Soares de Andréa. Em 1844, Andréa assumiu a presidência da província da Bahia, permanecendo no cargo até 1846. Mais tarde se tornaria o barão de Caçapava. Na sua administração, Andréa dedicou-se às obras e instrução públicas, sendo o primeiro presidente a demonstrar interesse especial pela Casa de Prisão com Trabalho. Em 21 de setembro de 1846, Andréa convocou uma comissão formada por engenheiros, médicos e juristas para estudar e apresentar soluções para a construção e para os demais assuntos que envolviam a implantação da

\footnotetext{
${ }^{108}$ Systema penitenciario, op. cit., p. 5.

${ }^{109}$ A partir de 1870, a freguesia da Nossa Senhora da Penha de França de Itapagipe foi desmembrada e o local da instituição passou a pertencer à freguesia de Nossa Senhora dos Mares. Sobre as freguesias do Arcebispado de São Salvador da Bahia no período de 1549 a 1889, ver SILVA, 2000, op. cit., p. 67-73. Atualmente esta área é conhecida como Baixa do Fiscal e, no edifício da antiga penitenciária, funciona o Hospital de Tratamento e Custódia da Bahia.

${ }^{110}$ Sessão da Câmara Municipal de 20 de novembro de 1833, fl. 41r ${ }^{\circ}$, AMS, Atas de Câmara, 1833-1835.
} 
Casa de Prisão com Trabalho. ${ }^{111}$ Para tanto, Andréa elaborou um questionário para ser estudado e respondido pelos estudiosos.

Tal como as respostas, as perguntas também contribuem para entendermos quais eram as preocupações do poder público com relação à implantação da penitenciária. Duas dessas perguntas são de grande relevância para nossa discussão: “A legislação actual do país se compadece, e até que ponto, com as instituições desse gênero, sendo que modificações na lei requerem a introdução do sistema penitencial do país?"112 Outra questionava "qual a regra que se deve seguir na administração e disciplina da prisão, e suas bases”. ${ }^{113}$ Esta última envolvia a escolha do sistema penitenciário. As respostas chegaram no ano seguinte, num minucioso relatório sustentado por idéias de reformadores estrangeiros como Charles Lucas e Alexis de Toqueville, além de relatos sobre as experiências penitenciárias norte-americanas e européias. Comecemos pela questão da legislação.

A comissão disse ser a primeira vez que um presidente da província tinha se preocupado em examinar "se as nossas leis consentiam transplantar de fora as instituições penitenciárias”, sendo este um “terreno virgem”. ${ }^{114}$ A comissão lembrou que a palavra sistema penitenciário somente foi citada na legislação brasileira em 1842, no Regulamento $n^{\circ} 120$, artigo 458 do parágrafo primeiro. ${ }^{115}$ A comissão criticou os legisladores do Código Criminal brasileiro.

Em 1841, quando parece que o que inspirava a reforma do codigo do processo era a necessidade de uma repressão mais forte aos crimes, a lei adoptando varias medidas, nem determinam, que o podia, o systema penitenciario, apezar do estar ella assistindo á ereção, em varios pontos do Imperio, de casas penitenciarias: como 11, ou 9 annos antes, em que se terminaram os nossos trabalhos de codificação criminal, o poderia ter feito? Não; os nossos codigos não se lembraram do systema penitenciario:

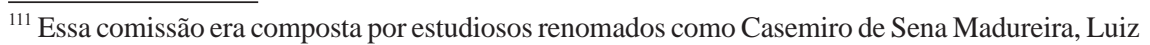
Maria Alves Falcão Moniz Barretto, Eduardo Ferreira França, João Baptista dos Anjos, Francisco Primo de Souza Aguiar, João Baptista Ferrari e João José Barboza de Oliveira; este último atuou como relator. Systema penitenciario, p. 3.

${ }^{112}$ Ibid., p. 41.

${ }^{113}$ Ibid., p. 7.

${ }^{114}$ Ibid., p. 41.

${ }^{115}$ Tal artigo, apontado pela comissão, cita o sistema penitenciário de forma indireta ao tratar das apelações. Regulamento $\mathrm{n}^{\circ} 120$, de 31 de janeiro de 1842, artigo 458. In: Colleção de Leis do Império,1842. Rio de Janeiro: Typografia Nacional, 1878, p. 121.
} 
por este tempo esta doutrina andava tão distante, tão pouco estudada, que quase se póde dizer que então germinava lá ao longe de nós - se então a legislação penal brasileira o ignorava existente, feliz ignorancia! Se o rejeitara obscuro, prudente regeição! ${ }^{116}$

A comissão sugeriu que fosse criada uma nova lei para reger a questão penitenciária a fim de não se alterar o Código Criminal, o que certamente seria mais demorado. ${ }^{117}$ Com relação às penas, a comissão destacou que a pena de morte e a prisão perpétua "estão mais ou menos em contradição ao systema penitenciário, o qual parte da idéia opposta á incorrigibilidade do criminoso”, mas que não iriam discutir esse assunto, por estar "além de sua missão". Quanto às penas de galés, a comissão foi um pouco mais além, dizendo que esta deveria ser automaticamente comutada por pena de prisão com trabalho. Para isso, o artigo 311 do Código Criminal deveria ser ampliado. "Art. 311. A pena de galés temporária será substituída pela de prisão com trabalho pelo mesmo tempo, logo que houver casas de correção nos lugares em que os réos estiverem cumprindo as sentenças”. ${ }^{118}$ Como a pena de galés era, sobretudo, aplicada aos escravos, embora não exclusivamente a eles, a comissão fez questão de esclarecer que não estava querendo beneficiá-los e sim lhes tirar um privilégio:

a vida dos galeotes comparada com a dos outros presos é muito melhor, mais sã, e menos constrangida [...] Deste modo convertido o patibulo, ou a calceta na prisão dentro em uma penitenciaria, os escravos não ficarão desherdados de todo do beneficio da regeneração moral, com que o sistema acena, e toda a penalidade que lhes impoem a lei não será só a morte, a galé e a mansilha, apertadas no tristissimo laconismo do barbaro artigo 60 do codigo criminal $[\ldots] .{ }^{119}$

De nada adiantou a sugestão da comissão em comutar a pena de galés para pena de prisão com trabalho. Afinal, o Código era lei imperial. O interessante é

\footnotetext{
${ }_{116}^{116}$ Systema penitenciario, op. cit., p. 45.

${ }^{117}$ Systema penitenciario, op. cit., p. 48.

${ }^{118}$ FILGUEIRAS JUNIOR, op. cit., p. 317.

${ }^{119}$ Systema Penitenciario, op. cit. p. 51. "Art. 60. Si o réo for escravo, e incorrer em pena que não seja a capital ou de galés, será condemnado na de açoutes, e, depois de os soffrer, será entregue a seu senhor, que se obrigará a traze-lo com um ferro, pelo tempo e maneira que o juiz designar”, FILGUEIRAS JUNIOR, op. cit. , p. 48.
} 
que, em 1850, um Aviso imperial veio, em sentido contrário, a alterar o teor do artigo 311. O benefício da comutação da pena foi limitado aos homens livres e os escravos perderam o suposto benefício de cumprir a pena de galés temporária nas penitenciárias: o Aviso dizia que a "substituição [da galés temporária por prisão com trabalho] não pode ser feita a respeito dos escravos: porque, em vista do art. 60, devem continuar a soffrer a pena de galés, visto como lhes não é applicável a de prisão com trabalho: Av. de 9 de agosto de 1850 ". ${ }^{120}$ A intenção de comutar a pena de galés em prisão com trabalho, mais do que beneficiar ou não o escravo, poderia estar relacionada em reduzir as diferenças da legislação, a fim de facilitar a adaptação do sistema penitenciário.

Conforme Aufderheide, as "punições diferenciadas para homens escravos e livres significava somente uma implementação parcial das reformas projetadas”. ${ }^{121}$ Para Ricardo Salvatore, a dualidade do Código Criminal perante o homem livre e o escravo foi um dos principais motivos do fracasso da reforma penitenciária no Brasil. Outros motivos citados pelo autor para o suposto fracasso foram a falta de continuidade dos planos do governo, as limitações financeiras e o regionalismo. ${ }^{122}$ Talvez o que Salvatore chama de fracasso deva ser atribuído ao que normalmente acontecia com as idéias liberais vindas de fora; ou seja, a implantação da penitenciária no Brasil sofreu um processo de adaptação à realidade local. ${ }^{123} \mathrm{O}$ autor ainda arrisca dizer que, no Brasil, a prisão era utilizada como uma "extensão do poder do senhor”. ${ }^{124}$ Não estou convencida quanto a essa sugestão de Salvatore, pois sabemos que, no Brasil, senhor e Estado se encontravam, muitas vezes, em lados opostos. ${ }^{125}$ Por exemplo, no caso do imperador perdoar o restante da pena de galés perpétua de um escravo, o que era comum numa primeira condenação, o escravo não era restituído à

\footnotetext{
${ }^{120}$ Ibid., p. 317.

${ }^{121}$ AUFDERHEIDE, Patrícia. Order and violence: social deviance and social control in Brazil, 1780-1840. Tese de doutorado em História, University of Minnesota, Minnesota, 1976, p. 332.

${ }^{122}$ SALVATORE, Ricardo, Penitentiares, visions of class, and export economies, op.cit., p. 200.

${ }^{123}$ Sobre o liberalismo, ver MARSON, Izabel Andrade. Liberalismo versus escravidão: reflexões sobre uma relação contraditória. História e Perspectivas, 24 (2002), p. 39-50; MATTOS, Ilmar Rohloff de. O tempo Saquarema: a formação do Estado imperial. São Paulo: Hucitec, 1990, SILVA, Mozart Linhares da. Do império da lei às grades da cidade. Porto Alegre: EDIPUCRS, 1997, entre outros.

${ }^{124}$ SALVATORE, Ricardo. Penitentiaries, visions of class, and export economies, op. cit., p. 200.

${ }^{125}$ Sobre este assunto ver SOARES, Carlos Eugênio Líbano. Escravos, senhores e policiais: o triângulo da desordem no Rio de Janeiro de dom João VI. Revista do Mestrado de História, ano II, Vassouras, (1999).
} 
escravidão. No ano de 1869, ao comentar essa questão, o conselheiro de Estado José Tomás Nabuco de Araujo observou que “o escravo, condenado a galés perpétuas, está para sempre perdido do senhor”. ${ }^{126}$ Portanto, o escravo preso era prejuízo para o senhor. Segundo Chalhoub, “as histórias de escravos - e ocasionalmente até libertos - que pensam poder recorrer à polícia no sentido de conseguir alguma proteção, ou mesmo que parecem cometer um crime com o objetivo de escapar a um destino indesejável, se sucedem com uma regularidade espantosa”. ${ }^{127}$ Contudo, essa é uma discussão mais ampla que merece ser abordada em trabalho específico.

Ao trazer à discussão tais questões, não estou a dizer que as idéias penitenciárias foram aderidas de forma impensada num contexto em que estariam fora de lugar. Pelo contrário, procuro destacar a complexidade, observada nos debates dos reformadores e autoridades da Bahia, no processo de implantação de um novo conceito de punição que deveria coexistir com práticas do antigo regime prisional, mantidas pelo Código Criminal do Império. A escravidão não dificultou apenas a reforma prisional; ela também foi uma barreira para a reforma jurídica mais ampla. Para Eduardo Pena, a elaboração de um código civil no período imperial não aconteceu por causa dos interesses senhoriais. ${ }^{128}$

A comissão eleita por Andréa foi bastante clara com relação à dificuldade de conciliar o regime penitenciário com a escravidão. Contudo, os seus membros chegaram à conclusão que tal tarefa não era impossível, afinal os Estados Unidos conviveram com essa situação. Eis a opinião da ilustre comissão sobre tal convivência.

No nosso estado social maiores repugnancias se não descobrem á introdução completa da innovação penitenciária, nem os elementos que o compoem são poderosos modificadores do systema. Esse obstáculo, ou essa causa modificadora, que da nossa constituição intima se erguesse, só no elemento escravo poderia consistir. Porém felizmente coetaneos com o Brasil lá estão os Estados Unidos, e a anologia aqui é bem legitima por mais de um titulo. Lá tem-se reparado que um sexto dos habitantes é de

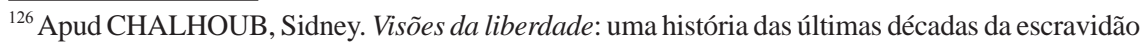
na Corte. São Paulo: Companhia das Letras, 1990, p. 179.

${ }^{127}$ Ibid., p. 176.

${ }^{128}$ Ver PENA, Eduardo Spiller. Pajens da casa imperial: jurisconsultos, escravidão e a lei de 1871. Campinas: Editora Unicamp, 2001.
} 
pretos, e que estes figuram por metade nas prisões. E, se é de observação que nos Estados do Norte, onde não ha escravos, as doutrinas penitenciárias, como tudo o mais vicejaram primeiro, e mais rapidas e perfeitas; e que dos 8 ou 9 Estados americanos, que ainda hoje não reformam os seos carceres, 6 , ou 7 são de escravos, tambem se tem observado que em alguns Estados do Sul, apesar da escravaria, casas penitenciarias se hão erguido. ${ }^{129}$

As sugestões de alterar o Código Criminal, bem como de criar uma lei específica para reger as questões penitenciárias, obviamente não saíram do papel. Quanto ao sistema penitenciário que deveria ser implantado na Casa de Prisão com Trabalho, a comissão preferiu o sistema da Pensilvânia. Com essa escolha, a comissão demonstrou não concordar com o contato físico dos presos: “a separação material, em que paredes colocam os encarcerados, atalha lhes todas as desenvolturas, e antecipadamente lhes tira até o mesmo pensamento da resistencia”. Foi alegado também que o trabalho coletivo, característica do sistema de Auburn, estimularia laços de amizade entre os presos, o que facilitaria mais tarde, quando soltos, possíveis parcerias criminosas. ${ }^{130}$ Entretanto, tal sugestão não significou a última palavra para as autoridades provinciais. Em 1863, o regulamento oficial da Casa de Prisão com Trabalho não adotou na íntegra nenhum dos modelos norte-americanos - Auburn ou Pensilvânia. Eu diria que, no máximo, o sistema de Auburn foi adaptado à realidade local, para não negar totalmente a influência estrangeira. ${ }^{131}$ As oficinas de ofício, principal característica do sistema penitenciário de Auburn, foram adotadas no regime disciplinar da Casa de Prisão com Trabalho e foram inauguradas em 1865. Infelizmente, não localizei o motivo que levou o governo a recusar o sistema da Pensilvânia, indicado pela comissão de 1847.

Assim como aconteceu em São Paulo e Rio de Janeiro, a Bahia também inaugurou a sua penitenciária com as obras incompletas. ${ }^{132}$ Na inauguração, em

\footnotetext{
${ }^{129}$ Ibid., p. 26.

${ }^{130}$ Ibid., p. 16.

${ }^{131}$ Regulamento da Casa de Prisão com Trabalho da Bahia. Aprovado pelo presidente da província, o conselheiro Antonio Coelho de Sá e Albuquerque, em 14 de outubro de 1863. Bahia: Typ. Poggetti, de Tourinho, Dias \& C, 1863, Bahia: Typ. Poggetti, 1863, BMSB, Obras raras. Sou grata ao professor João Reis pela localização deste documento.

${ }^{132}$ A Casa de Correção de São Paulo foi inaugurada em 1852, com apenas um raio construído, com capacidade para 40 presos. Somente em 1855 ficou pronto o segundo raio aumentando a capacidade da Casa para 80 presos. No final da década o terceiro raio foi concluído e a capacidade total da instituição passou para 120 presos. SALLA, op. cit., p. 65-67. A Casa de Correção da Corte foi
} 
1861, a Casa de Prisão com Trabalho tinha capacidade para duzentos presos e, para acomodá-los, contava com dois raios construídos - leste e oeste - e com 144 celas. O denominado raio do oeste tinha três pavimentos e ali ficariam os aposentos dos funcionários, a enfermaria e a administração, além das cinco oficinas. No outro raio estavam localizadas as celas. O pavimento térreo contava com 36, sendo 18 de cada lado, coincidindo com o primeiro andar, que comportava o mesmo número. Em cada cela destes pavimentos foram alojados dois presos, revelando que o isolamento, tão caro às doutrinas penitenciárias, não era seguido. No segundo andar ficavam as celas individuais, em número de 72, sendo 36 em cada lado. Entre elas estavam seis solitárias, utilizadas para as punições disciplinares previstas no regulamento. As celas não eram padronizadas e algumas eram fechadas "de alto a baixo, tendo apenas um pequeno postigo por onde o prezo gosa de algum ar”. Nas palavras do administrador, esse quadro tornava as celas um local "de castigo e martirio". ${ }^{133}$ Tal descrição nos faz lembrar as cadeias do antigo regime prisional, onde a falta de ar e de luz eram crônicas. Para agravar a situação, as obras impediam o passeio dos presos, fazendo com que os mesmos permanecessem confinados nos cubículos, exceto na ocasião da faxina. ${ }^{134}$ Conforme Roberto Machado, a pouca luz e ventilação nos cárceres são alguns dos elementos que os transformam em locais de doença e de morte. ${ }^{135}$

Os debates sobre o sistema prisional na Bahia podem ter se assemelhado aos das outras províncias, mas, na prática, a penitenciária baiana teve lá as suas peculiaridades. Por exemplo, cito o fato das casas de Correção da Corte e de São Paulo servirem também como local de castigos de escravos, onde os mesmos eram trancafiados em calabouços. ${ }^{136}$ Com relação à Bahia, não encontrei evidências de escravos sofrendo penas de açoite na Casa de Prisão com Trabalho. Tampouco existiam ali os calabouços. Os escravos eram castigados nas cadeias

inaugurada em 1850, com o primeiro raio ainda incompleto. Depois de pronto, teria capacidade para 200 presos. Suas obras continuaram por mais dezessete anos. PESSOA, op. cit., p. 81.

${ }^{133}$ Relatório da comissão inspetora para o presidente da província, (25/02/1862), APEBa, Casa de Prisão, 1836-1868, maço 3082; Administrador da CPCT para o chefe de polícia, (22/08/1864), APEBa, Mapa de presos, 1864-1867, maço 6273.

${ }^{134}$ Relatório da comissão inspetora ao presidente da província, op. cit.

${ }^{135}$ MACHADO, Roberto et alii. A danação da norma: medicina social e constituição da psiquiatria no Brasil. Rio de Janeiro: Graal, 1978, p. 317.

${ }^{136}$ Para São Paulo, ver SALLA, op. cit., e para o Rio de Janeiro, ver PESSOA, op. cit. 
e na prisão dos galés do Arsenal de Marinha. ${ }^{137}$ Embora a pena de prisão com trabalho coubesse apenas a pessoa livre ou liberta, no período de 1861 a 1865 , a população carcerária da penitenciária era formada basicamente por homens livres, pardos e crioulos. ${ }^{138}$ De um total de 111 presos que levantei, no período de 1861 a 1865 , apenas 16 eram mulheres. ${ }^{139} \mathrm{Em} 1865$, elas foram transferidas para a cadeia da Correção que, a partir de então, passou a recebê-las, pelo menos até o final do século XIX. ${ }^{140}$ Lembre-se que a cadeia da Correção não possuía estrutura compatível com a política do aprisionamento moderno, ou seja, ali a população carcerária cumpria pena aos moldes do antigo regime prisional.

Por fim, é possível dizer que a penalidade moderna foi implantada na Bahia com a inauguração da Casa de Prisão com Trabalho, mas a cadeia da Correção e a prisão dos galés do Arsenal da Marinha continuaram a reproduzir as práticas do antigo regime prisional, como o açoitamento de escravos e o trabalho forçado, penas previstas no Código Criminal do Império. Mesmo sem o rigor dos modelos estrangeiros, a construção das penitenciárias, no Brasil oitocentista, denominadas casas de correção e, especificamente na Bahia, de Casa de Prisão com Trabalho, anunciou uma nova era na história do sistema prisional brasileiro.

\section{Fontes e referências bibliográficas}

\section{Ilustração}

ALBERNAZ, Francisco Mangabeira. Aquarela. Reprodução gentilmente cedida pelo professor João José Reis.

\footnotetext{
${ }^{137}$ Vários despachos do chefe de polícia para os carcereiros das cadeias da Correção e do Barbalho autorizam castigos de escravos, APEBa, Polícia, Correspondência expedida, 1861-1862, maço 5745 .

${ }^{138}$ Sobre o perfil dos presos da Casa de Prisão com Trabalho no período de 1861-1865, ver TRINDADE, Cláudia Moraes. A Casa de Prisão com Trabalho da Bahia, 1833-1865. Dissertação de mestrado em História Social, Universidade Federal da Bahia, Salvador, 2007, terceiro capítulo. ${ }^{139}$ Guias de transferência de presos para a CPCT, APEBa, Polícia, Casa de Prisão, 1861-1886, maço 5942; Cento e setenta e dois presos que se achão actualmente recolhidos nesta Casa, (29/09/1865), APEBa, Mapa de presos, 1864-1869, maço 6287; Relação de presos da Cadeia da correção, APEBa, Cadeias, 1857-1861, maço 6271.

${ }^{140}$ Relatório do administrador interino ao chefe de polícia, (20/09/1865), APEBa, Polícia, Mapa de presos, 1864-1867, maço 6273; SEIXAS, op. cit., p. 51.
} 


\section{Fontes impressas}

Almanaque civil político e comercial da cidade da Bahia para o ano de 1845. Edição fac-similar. Salvador: Fundação Cultural, 1998.

Regulamento da Casa de Prisão com Trabalho da Bahia. Aprovado pelo presidente da província o conselheiro Antonio Coelho de Sá e Albuquerque, em 14 de outubro de 1863. Bahia: Typ. Poggetti, de Tourinho, Dias \& C, 1863; Bahia: Typ. Poggetti, 1863

BEAUMONT Gustave de, TOCQUEVILLE. Du système pénitentiaire aux ÉtatsUnis et de son application en France, suivi d'un appendice sur les colonies pénales et de notes statistiques, 2 vols. Paris: Impr. de H. Fournier, 1833, 2e éd., Paris: C. Gosselin, 1836.

BRASIL. Colleção das Leis do Império do Brazil. Rio de Janeiro: Typografia Nacional, 1878.

FILGUEIRAS JUNIOR, Araujo. Código Criminal do Império do Brazil Annotado. Rio de Janeiro: Eduardo \& Henrique Laemmert, 1876.

LARA, Silvia Hunold Lara. (org). Ordenações Filipinas: livro V. São Paulo: Companhia das Letras, 1999.

OLIVEIRA, João José Barboza de. As prisões do paiz: o systema penitencial, ou hygiene penal. These apresentada, e sustentada perante a Faculdade de Medicina da Bahia, em 11 de dezembro de 1843. Bahia: Typ. de L.A. Portella e Companhia, 1843.

SEIXAS, Eustaquio Primo de Seixas. Considerações sobre o systema penitenciario adoptado pelo Codigo Penal vigente. These apresentada ao concurso para preenchimento de uma vaga aberta no Tribunal de Appellação e Revista do Estado da Bahia, em 25 de outubro de 1897. Bahia: Typographia e Encadernação do Diario da Bahia, 1897.

\section{Livros, artigos e teses}

AUFDERHEIDE, Patrícia. Order and violence: social deviance and social control in Brazil, 1780-1840. Tese de doutorado em História, University of Minnesota, Minnesota, 976.

ARAÚJO, Carlos Eduardo Moreira. O duplo cativeiro: escravidão urbana e o sistema prisional no Rio de Janeiro, 1790-1821. Dissertação de mestrado em História, Universidade Federal do Rio de Janeiro, Rio de Janeiro, 2004.

AGUIRRE, Carlos. The criminals of Lima and their worlds: the prison experience, 1850-1935. Durham: Duke University Press, 2005.

BAUMANN, Thereza de B. Da iconografia, da loucura, da história. Revista de História Regional, vol. 2, nº 1, 1997. 
COELHO, Edmundo Campos. As profissões imperiais: medicina, engenharia e advocacia no Rio de Janeiro (1822-1930). Rio de Janeiro: Record, 1999.

FOUCAUT, Michel. Os anormais: curso no Collège de France (1974-1975). Tradução de Eduardo Brandão. São Paulo: Martins Fontes, 2001.

Vigiar e punir: história da violência nas prisões, 5. ed. Petrópolis: Vozes, 1987.

Prisões e revoltas nas prisões. In: MOTA, Manoel Barros da (org.). Michel Foucault: estratégia, poder-saber. Rio de Janeiro: Forense Universitária, 2003, p. 61-80.

FRAGA FILHO, Walter. Mendigos, moleques e vadios na Bahia do século XIX. Salvador: EDUFBA, 1999.

FLORENCE, Afonso Bandeira. Entre o cativeiro e a emancipação: a liberdade dos africanos livres no Brasil (1818-1854).Dissertação de Mestrado em História, Universidade Federal da Bahia, Salvador, 2002.

HOLLOWAY, Thomas H. Polícia no Rio de Janeiro: repressão e resistência numa cidade do século XIX. Rio de Janeiro: Fundação Getúlio Vargas, 1997.

IGNATIEFF, Michael. Instituições totais e classes trabalhadoras: um balanço crítico. Revista Brasileira de História, 14, 1987, p. 185-193.

LEAL, César Barros. Prisão: crepúsculo de uma era. 2. ed. revista e atualizada. Belo Horizonte: Del Rey editora, 2001.

MACHADO, Roberto et alii. A danação da norma: medicina social e constituição da psiquiatria no Brasil. Rio de Janeiro: Graal, 1978.

MCGOWEN, Randall. The well-ordered prison: England, 1780-1865. In: MORRIS, Norval; ROTHMAN, David J. (orgs.), The Oxford history of the prison. New York: Oxford University Press, 1995, p. 79-109.

MOREL, Marco. Cipriano Barata na Sentinela da Liberdade. Salvador: Academia de Letras da Bahia, Assembléia Legislativa do Estado da Bahia, 2001.

O'BRIEN, Patricia. The prison on the continent, Europe 1865-1965. In: MORRIS, Norval; ROTHMAN, David J. (orgs.), The Oxford history of the prison. New York: Oxford University Press, p. 178-201.

PAIVA, Helena Marisa Vianna. A Casa de Correção de Porto Alegre, 1889-1898. Dissertação de mestrado em História, Pontifícia Universidade Católica do Rio Grande do Sul, Porto Alegre, 2002.

PENA, Eduardo Spiller, Pajens da casa imperial: jurisconsultos, escravidão e a lei de 1871. Campinas: Editora Unicamp, 2001.

PERROT, Michelle. Os excluídos da história: operários, mulheres e prisioneiros. 3. ed. São Paulo: Paz e Terra, 2001.

. O inspetor Bentham. In: SILVA,Tomaz Tadeu da (org.). Jeremy Bentham, o panótico. Belo Horizonte: Autêntica, 2000, p. 109-149. 
PESSOA, Gláucia Tomaz de Aquino. Trabalho e resistência na penitenciária da Corte 1850-1876. Dissertação de mestrado em História, Universidade Federal Fluminense, Rio de Janeiro, 2000.

REIS, João José. Rebelião escrava no Brasil: a história do levante dos malês em 1835. Edição revista e ampliada. São Paulo: Companhia das Letras, 2003. . A morte é uma festa: ritos fúnebres e revolta popular no Brasil do século XIX. São Paulo: Companhia das Letras, 1991.

ROTHMAN, David J. Perfecting the prison: Unides States, 1789-1865. In: MORRIS Norval; ROTHMAN David J. (orgs.). The Oxford history of the prison. New York: Oxford University Press, 1995. p. 100-116.

RUY, Affonso. A Relação da Bahia, contribuição para a história judiciária do Brasil. 2. ed. Salvador: Tribunal de Justiça do Estado da Bahia, 1996.

SALLA, Fernando A. O encarceramento em São Paulo: das enxovias à penitenciária do Estado. Tese de doutorado em Sociologia, Universidade de São Paulo, São Paulo. 1997.

. Os escritos de Alexis de Tocqueville e Gustave de Beaumont sobre a prisão: o problema da participação dos negócios privados. Revista Plural. São Paulo: USP, $\mathrm{n}^{\circ} 1$ 1, 1994, p. 1-16.

SILVA, Alberto. A cidade de Salvador: aspectos seculares. Salvador: Imprensa Oficial da Bahia, 1971.

SILVA, Mozart Linhares da. Do império da lei às grades da cidade. Porto Alegre: EDIPUCRS, 1997.

SALVATORE, Ricardo, Penitentiares, visions of class, and export economies. In: SALVATORE, Ricardo e AGUIRRE, Carlos (orgs). The birth of the penitentiary in Latin America: essays on criminology, prison reform, and social control, 1830-1940. Austin: University of Texas Press, 1996.

SILVA, Cândido da Costa. Os segadores e a messe: o clero oitocentista na Bahia. Salvador: SCT, EDUFBA, 2000.

SILVA, Tomaz Tadeu da (org. e tradução). Jeremy Bentham, o panótico. Belo Horizonte: Autêntica, 2000.

SOARES, Carlos Eugênio Líbano. A negregada instituição: os capoeiras na corte imperial 1850-1890. Rio de Janeiro: Access, 1999.

. A capoeira escrava e outras tradições rebeldes no Rio de Janeiro, 18081850. Campinas: Editora da Unicamp, 2003.

. Escravos, senhores e policiais: o triângulo da desordem no Rio de Janeiro de dom João VI. Revista do Mestrado de História, ano II, Vassouras, 1999.

SOUZA, Paulo Cezar. A Sabinada: revolta separatista da Bahia (1837). São Paulo: Brasiliense, 1987.

TAVARES, João Henrique. Ecos do porão. In: Revista Nossa História, 12 (2004). 
TRINDADE, Cláudia Moraes. A Casa de Prisão com Trabalho da Bahia, 18331865. Dissertação de mestrado em História Social, Universidade Federal da Bahia, Salvador, 2007.

THOMPSON, E. P. Senhores e caçadores. Rio de Janeiro: Paz e Terra, 1987.

WILDBERGER, Arnoldo. Os presidentes da provincia da Bahia, efetivos e interinos. Cidade do Salvador: Tipografia Beneditina, 1949. 